\title{
Characteristics of surface ozone in Agra, a sub-urban site in Indo-Gangetic Plain
}

\author{
Nidhi Verma, Aparna Satsangi, Anita Lakhani and K Maharaj Kumari* \\ Department of Chemistry, Dayalbagh Educational Institute, Dayalbagh, Agra 282 110, India. \\ *Corresponding author.e-mail: maharajkumari.k@rediffmail.com
}

MS received 7 March 2017; revised 3 August 2017; accepted 7 August 2017; published online 9 April 2018

In the present study, measurements of surface ozone $\left(\mathrm{O}_{3}\right)$ and its precursors $\left(\mathrm{NO}\right.$ and $\left.\mathrm{NO}_{2}\right)$ were carried out at a sub-urban site of Agra $\left(27^{\circ} 10^{\prime} \mathrm{N}, 78^{\circ} 05^{\prime} \mathrm{E}\right)$, India during May 2012-May 2013. During the study period, average concentrations of $\mathrm{O}_{3}, \mathrm{NO}$, and $\mathrm{NO}_{2}$ were $39.6 \pm 25.3,0.8 \pm 0.8$ and $9.1 \pm 6.6 \mathrm{ppb}$, respectively. $\mathrm{O}_{3}$ showed distinct seasonal variation in peak value of diurnal variation: summer $>$ postmonsoon $>$ winter $>$ monsoon. However, $\mathrm{NO}_{2}$ showed highest levels in winter and lowest in monsoon. The average positive rate of change of $\mathrm{O}_{3}(08: 00-11: 00 \mathrm{hr})$ was highest in April $(16.3 \mathrm{ppb} / \mathrm{hr})$ and lowest in August (1.1 ppb/hr), while average negative rate of change of $\mathrm{O}_{3}$ (17:00-19:00 hr) was highest in December $(-13.2 \mathrm{ppb} / \mathrm{hr})$ and lowest in July $(-1.1 \mathrm{ppb} / \mathrm{hr})$. An attempt was made to identify the VOC- $\mathrm{NO}_{\mathrm{x}}$ sensitivity of the site using $\mathrm{O}_{3} / \mathrm{HNO}_{3}$ ratio as photochemical indicator. Most of the days this ratio was above the threshold value (12-16), which suggests $\mathrm{NO}_{\mathrm{x}}$ sensitivity of the site. The episodic event of ozone was characterized through meteorological parameters and precursors concentration. Fine particles $\left(\mathrm{PM}_{2.5}\right)$ cause loss of ozone through heterogeneous reactions on their surface and reduction in solar radiation. In the study, statistical analyses were used to estimate the amount of ozone loss.

Keywords. Surface ozone; $\mathrm{O}_{3} / \mathrm{HNO}_{3}$ ratio; long-range transport; $\mathrm{PM}_{2.5}$.

\section{Introduction}

Ozone $\left(\mathrm{O}_{3}\right)$ is a secondary pollutant which has an important effect on air quality, climate change and atmospheric chemistry (Solomon et al. 2000; Sitch et al. 2007). Depending on its location in the atmosphere, $\mathrm{O}_{3}$ can influence human health and climate; in the stratosphere, $\mathrm{O}_{3}$ filters out detrimental ultraviolet radiations while in the troposphere, it is a constituent of photochemical smog (Gurjar et al. 2010). In plants, ozone slows down photosynthetic activity and causes degradation of protein and chlorophyll (Mauzerall and Wang 2001; Fuhrer 2009). Ozone is third most important greenhouse gas (IPCC 2007; Racherla and Adams
2008) and an important source of hydroxyl radicals $\left(\mathrm{OH}^{\circ}\right)$.

In the troposphere, $\mathrm{O}_{3}$ is formed by two major mechanisms: (i) Stratosphere to troposphere transport (Lelieveld and Dentener 2000) and (ii) Photochemical production through the oxidation of carbon monoxide $(\mathrm{CO})$, methane $\left(\mathrm{CH}_{4}\right)$, non-methane hydrocarbons (NMHCs) and other volatile organic compounds (VOCs), the reaction is controlled and catalyzed by $\mathrm{NO}_{\mathrm{x}}\left(\mathrm{NO}\right.$ and $\mathrm{NO}_{2}$ ) (Jonson et al. 2006). Biomass burning, fossil fuel combustion, and other anthropogenic activities generate $\mathrm{CO}, \mathrm{CH}_{4}$, and VOCs (Cetin et al. 2003). $\mathrm{NO}_{\mathrm{x}}$ is emitted into the atmosphere by natural (microbial activity in soil and lightning, etc.) as well as anthropogenic 
sources (biomass burning and combustion of fossil fuel) (Lamarque et al. 1996; Bond et al. 2001; Beevers et al. 2012).

Ozone formation is a highly nonlinear cycle and $\mathrm{O}_{3}$ has a complex relationship with its precursors (VOCs and $\mathrm{NO}_{\mathrm{x}}$ ). Depending on ozone's relationship with VOCs and $\mathrm{NO}_{\mathrm{x}}$, two categories of regimes have been classified: $\mathrm{NO}_{\mathrm{x}}$-sensitive and VOC-sensitive (Sillman 1995, 1999). In $\mathrm{NO}_{\mathrm{x}}$-sensitive regime, the rate of ozone production rises with the rise in $\mathrm{NO}_{\mathrm{x}}$ concentration while in the VOC-sensitive regime, the rate of ozone production rises with the rise in VOCs concentration. Different models and measurement techniques have been used to identify ozone-VOC-NO sensitivity (Peng et al. 2006; Kumar et al. 2008; Tseng et al. 2009). However, three-dimensional photochemical model simulations for evaluation of ozone-VOC- $\mathrm{NO}_{\mathrm{x}}$ sensitivity are difficult because of the uncertainties of model assumptions (Fujita et al. 1992; Bishoi et al. 2009). One alternative approach is to use photochemical indicator species or species ratios such as $\mathrm{O}_{3} / \mathrm{NO}_{\mathrm{y}}, \mathrm{H}_{2} \mathrm{O}_{2} / \mathrm{HNO}_{3}, \mathrm{PAN} / \mathrm{O}_{3}, \mathrm{O}_{3} / \mathrm{HNO}_{3}$ and $\mathrm{NO}_{\mathrm{x}} / \mathrm{NO}_{\mathrm{y}}$ (Im et al. 2011; Peng et al. 2011). Peng et al. (2011) conducted their study using photochemical indicators $\left(\mathrm{H}_{2} \mathrm{O}_{2} / \mathrm{HNO}_{3}, \mathrm{O}_{3} / \mathrm{HNO}_{3}\right.$, $\mathrm{O}_{3} / \mathrm{NO}_{\mathrm{y}}$ ) at three sites in southern Taiwan and reported two rural sites as $\mathrm{NO}_{\mathrm{x}}$-sensitive and an urban site as VOC-sensitive. In addition to precursors' concentration, ozone levels are significantly influenced by meteorology parameters which play an important role in its formation and transport (Elminir 2005; Tu et al. 2007).

Seasonal and diurnal variation of surface ozone and its precursors have been extensively studied at different sites around the world (Aneja et al. 1997; Nair et al. 2002; Debaje et al. 2003; Naja et al. 2003; Lehman et al. 2004; Satsangi et al. 2004; Yang et al. 2005; Singla et al. 2011; Nishanth et al. 2012; Zhang et al. 2013). Aneja et al. (1997) identified ozone and its relationship with $\mathrm{NO}, \mathrm{NO}_{\mathrm{y}}$ and $\mathrm{CO}$ at downtown, North Carolina. At their site, air-masses were predominantly affected by fresh emissions of $\mathrm{CO}$ and $\mathrm{NO}_{\mathrm{y}}$ (high $\mathrm{NO}$ ) which led to low levels of $\mathrm{O}_{3}$. Nair et al. (2002) carried out their study at the coastal site of Thumba, India and compared it with the urban site of Ahmedabad. At Thumba, despite low levels of CO and $\mathrm{NO}_{\mathrm{x}}$, ozone levels were not significantly low. Naja et al. (2003) conducted their study at the high altitude site of Mt. Abu where ozone did not show daytime rise. However, Nishanth et al. (2012) observed the daytime increase in ozone levels at rural coastal site Kannur, India but the seasonal maximum was observed in the winter season. Few studies have also reported variations of ozone and its precursors in Indo-Gangetic Plain (IGP) (Beig and Ali 2006; Lal et al. 2008; Shukla et al. 2017). Beig and Ali (2006) studied ozone and precursors levels over IGP using model simulations. Lal et al. (2008) analyzed trace gases $\left(\mathrm{O}_{3}, \mathrm{NO}_{\mathrm{x}}\right.$ and $\mathrm{CO})$ during December in Hissar situated in northwestern region of IGP. They observed elevated levels of ozone during clear sky days as compared to foggy days and used ratios of different primary emissions to conclude that their site was affected by fresh emissions from biomass burning. Shukla et al. (2017) conducted their study at two sites; Varanasi and Lucknow. They compared ground levels measurements of ozone with satellite data which showed significant correlation. Their study also involved correlation analysis of ozone with meteorological parameters.

Earlier studies (Singla et al. 2011, 2012) at the present site have focused on diurnal, seasonal variation of ozone, $\mathrm{NO}$ and $\mathrm{NO}_{2}$. In addition, the effect of different meteorological parameters had also been discussed. However, in recent years, sharp increase in ozone levels is observed which may affect human health as well as staple crops. Therefore, the present study was initiated to add new insights about the relationship of ozone and $\mathrm{NO}_{2}$, ozone episodic levels and relationship of ozone and $\mathrm{PM}_{2.5}$. The study was designed to determine diurnal and seasonal variations of $\mathrm{O}_{3}$ and its precursors ( $\mathrm{NO}$ and $\mathrm{NO}_{2}$ ) and their comparison with other geographically different sites in India during May 2012-May 2013. The $\mathrm{O}_{3}-\mathrm{VOC}-\mathrm{NO}_{\mathrm{x}}$ sensitivity of the site was determined using $\mathrm{O}_{3} / \mathrm{HNO}_{3}$ ratio as a photochemical indicator. Further, an $\mathrm{O}_{3}$ episodic event was analyzed using precursor levels and meteorological parameters. Loss of $\mathrm{O}_{3}$ through $\mathrm{PM}_{2.5}$ was calculated using regression analysis.

\section{Site description}

The study was carried out at a sub-urban site of Dayalbagh, Agra $\left(27^{\circ} 10^{\prime} \mathrm{N}, 78^{\circ} 05^{\prime} \mathrm{E}\right)$. The site is located in Indo-Gangetic Plain and has a semiarid climate as it is surrounded by the Thar Desert of Rajasthan on two-thirds of its periphery (figure 1). The detailed description of the site has been discussed elsewhere (Verma et al. 2015). The site has four distinct seasons; summer (MarchJune), monsoon (July-September), post-monsoon 


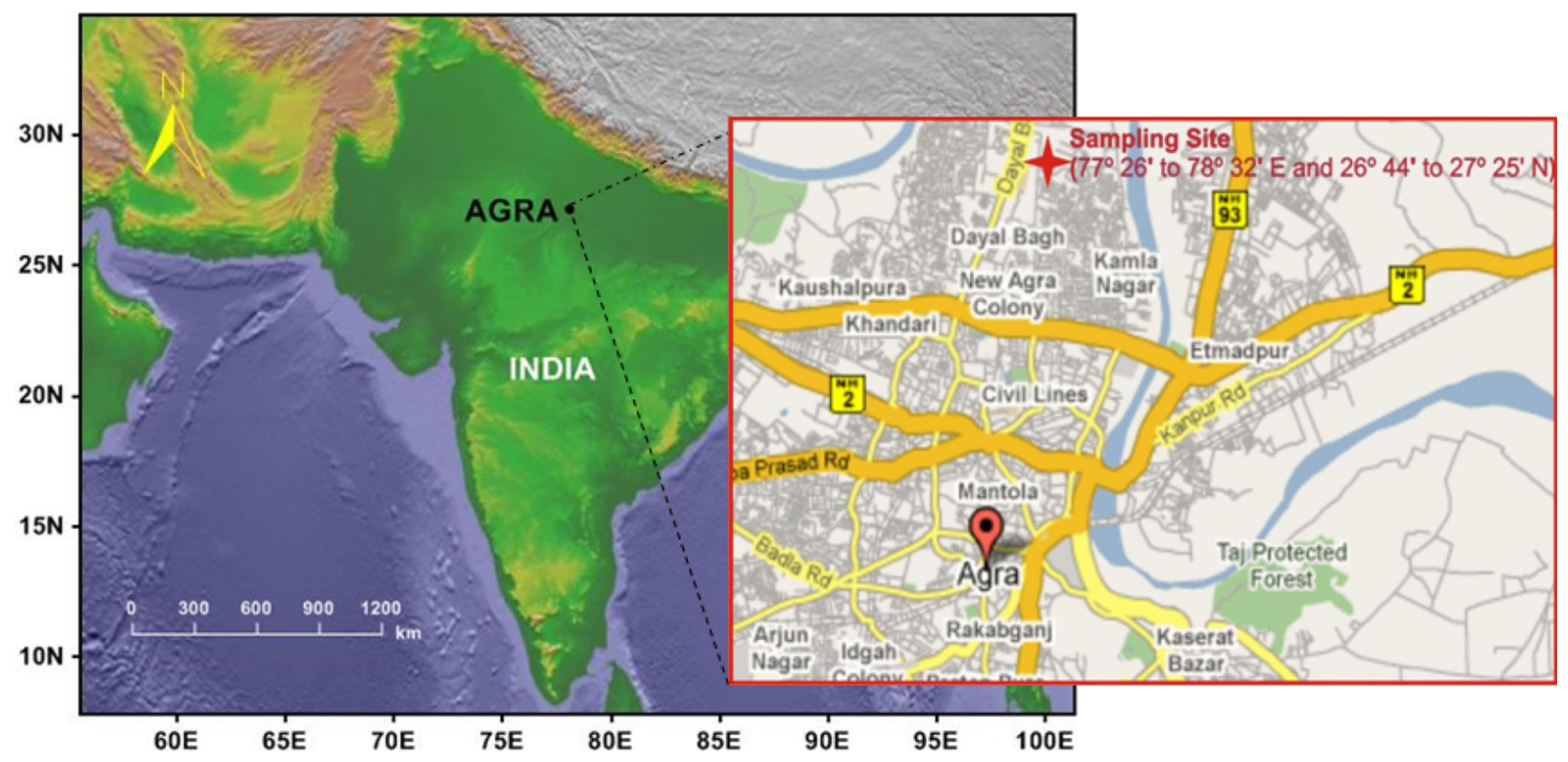

Figure 1. Map of sampling site (shown by star) at Dayalbagh, Agra, India.

(October and November) and winter (DecemberFebruary). In the summer season, the temperature ranged between 22 and $47^{\circ} \mathrm{C}$ (avg. $31 \pm 6.8^{\circ} \mathrm{C}$ ), while relative humidity $(\mathrm{RH})$ ranged between 14 and $60 \%$ (avg. $43 \pm 20 \%$ ). In the winter season, the temperature dropped to below $3^{\circ} \mathrm{C}$ (avg. $15.5 \pm$ $6.0^{\circ} \mathrm{C}$ ) and relative humidity ranged from 23 to $90 \%$ (avg. $70 \pm 20 \%$ ). In the post-monsoon season, temperature ranged from 11 to $38.5^{\circ} \mathrm{C}(25.9 \pm$ $6.1^{\circ} \mathrm{C}$ ) and $\mathrm{RH}$ ranged from 20 to $94 \%(64.3 \pm 19 \%)$. In monsoon season, because of heavy rainfall, $\mathrm{RH}$ ranged from 45 to $98 \%(78.9 \pm 14.4 \%)$ and temperature varied from 22 to $40^{\circ} \mathrm{C}\left(30.2 \pm 3.1^{\circ} \mathrm{C}\right)$.

\section{Methodology}

Continuously operating $\mathrm{O}_{3}$ (Thermo Fischer Model $49 i$ ) and $\mathrm{NO}_{\mathrm{x}}$ analyzer (Thermo Fischer Model $42 i$ ) have been used for the measurements of surface $\mathrm{O}_{3}$ and $\mathrm{NO}_{\mathrm{x}}$ concentrations, respectively. For sampling, air is passed through a sampling manifold to remove moisture and then through a polytetrafluoroethylene (PTFE) filter $(5 \mu \mathrm{m}$, Sartorius AG, Germany) to remove dust and particles before entering the analyzer. The ozone concentration measurement is based on ultraviolet light absorption at $254 \mathrm{~nm}$ wavelength. The concentration of ozone in air is calculated by the analyzer using Lambert-Beer law. The detection limit of ozone analyzer is $1.0 \mathrm{ppb}$, response time is $20 \mathrm{~s}$ and accuracy is $\pm 5 \%$. The zero drift of ozone analyzer is
$<1.0 \mathrm{ppb}$ for $24 \mathrm{hrs}$. The $\mathrm{NO}_{\mathrm{x}}$ analyzer operates on the principle of chemiluminescence. Nitric oxide (NO) present in sample air react with $\mathrm{O}_{3}$ (generated by the analyzer) to form $\mathrm{NO}_{2}$ molecules which emit a characteristic luminescence in infrared (IR) region. The intensity of IR radiation is linearly proportional to the NO concentration. Since this method is specific for NO measurements, therefore, $\mathrm{NO}_{2}$ measurement was based on the conversion of $\mathrm{NO}_{2}$ into $\mathrm{NO}$ using a molybdenum (Mo) converter. Molybdenum has $\sim 100 \%$ conversion efficiency (Pitts and Pitts 2000). The detection limit and response time of $\mathrm{NO}_{\mathrm{x}}$ analyzer are $0.4 \mathrm{ppb}$ and $80 \mathrm{~s}$, respectively for $60 \mathrm{~s}$ averaging time. The zero drift of $\mathrm{NO}_{\mathrm{x}}$ analyzer is $<0.4 \mathrm{ppb}$ for $24 \mathrm{hrs}$.

To maintain the accuracy, the analyzers were regularly checked for zero and span calibrations. Zero check was performed on a weekly basis, while span checks were performed on monthly basis. For zero air generation, compressed air is first passed through silica gel then through purafil and charcoal. For span check, ozone analyzer has in-built ozone generator, while for $\mathrm{NO}_{\mathrm{x}}$ analyzer, span gas cylinder of $\mathrm{NO}$ (NIST traceable $\mathrm{NO}$ in $\mathrm{N}_{2}$ ) was used through multipoint calibrator (Teledyne model, T700). The data can be recorded at the intervals of $1 \mathrm{~min}$ to $24 \mathrm{hr}$ with the help of data acquisition systems. In the present study, 1-hr average data was selected.

Gaseous $\mathrm{HNO}_{3}$ samples $(N=60)$ were collected to determine $\mathrm{NO}_{\mathrm{x}}-\mathrm{VOC}$ sensitivity. $\mathrm{HNO}_{3}$ samples were collected using a low-volume sampler 
(vayubodhan) at a flow rate of $2 \mathrm{~L} \mathrm{~min}^{-1}$. For the collection of $\mathrm{HNO}_{3}$, distilled water $(25 \mathrm{ml})$ was used as absorbing media. The collected $\mathrm{HNO}_{3}$ samples were analyzed by ion chromatography (Dionex ICS-1100) (Kumar et al. 2004). The eluent used for analysis was $6.0 \mathrm{mM} \mathrm{NaOH}$ and ICS was equipped with a guard column (AG 11) and analytical column (AS11). For standardisation of the method, sodium nitrate ( $>99.0 \%$ purity) was procured from Sigma-Aldrich (St. Louis, MO, USA). The stock solution of $1000 \mathrm{mg} \mathrm{L}^{-1}$ was prepared and stored at $-18^{\circ} \mathrm{C}$ from which working standards were prepared when required. The limit of detection, relative error and relative standard deviation were $5.9 \mathrm{ng} \mathrm{m}^{-3}, 1.4$ and $0.7 \%$, respectively.

$\mathrm{PM}_{2.5}$ samples $(N=55)$ were collected on 47 $\mathrm{mm}$ quartz fibre filters (Pallflex, Tissuquartz) using fine particulate sampler (Envirotech APM 550). The detailed description of particulate sample collection and analysis has been discussed elsewhere (Verma et al. 2016). The present site being $1300 \mathrm{~km}$ inland of sea and has an average RH of $51.2 \pm 14.2 \%$, therefore, no correction for $\mathrm{RH}$ was made, as it has more significance on coastal aerosols which are hygroscopic in nature. According to Moorthy et al. (2010), the effect of RH becomes more significant at $\mathrm{RH}>80 \%$. During the study period, only on $18 \%$ of days, $\mathrm{RH}$ was greater than $80 \%$. However, to counter this positive artefact, particulate samples were placed in desiccators before and after sampling until their mass was stabilized. Earlier studies have also used the similar method to calculate mass concentration of particulate samples (Clements et al. 2014; Yadav et al. 2015).

Meteorological parameters, viz., solar radiation, temperature, relative humidity and wind speed were recorded at sampling site using Automatic Weather Station WM271 Data Logger at every 1-hr interval. The monthly mean Planetary Boundary Layer (PBL) height in a grid of $0.5 \times 0.5^{\circ}$ was calculated from GDAS NOAA ARL (https://www. ready.noaa.gov/) daily values. The diurnal variation of temperature, $\mathrm{RH}$ and solar radiations (SR) in different seasons over the study period is shown in figure $2(\mathrm{a}-\mathrm{c})$. Diurnal pattern of temperature for four seasons was characterized by high value during daytime $\left(22-38^{\circ} \mathrm{C}\right)$ and low value during the night and early morning $\left(10-25^{\circ} \mathrm{C}\right)$ hours. Solar radiation also showed the similar diurnal pattern in all seasons while relative humidity showed an opposite pattern. The monthly mean PBL height shows highest value $(1666 \mathrm{~m})$ in June and lowest $(222 \mathrm{~m})$ in December (figure 2d).

\section{Results and discussion}

\subsection{Diurnal variation of ozone and its precursors}

At the present site, average concentrations of $\mathrm{O}_{3}$, $\mathrm{NO}$, and $\mathrm{NO}_{2}$ were $39.6 \pm 25.3,0.8 \pm 0.8$ and $9.1 \pm 6.6 \mathrm{ppb}$, respectively. Figure 3 shows diurnal pattern of ozone, $\mathrm{NO}$, and $\mathrm{NO}_{2}$; average diurnal pattern of ozone was characterized by minimum value of $20.3 \pm 9.6 \mathrm{ppb}$ during early morning hours $(\sim 7: 00 \mathrm{hr})$, reached a maximum value of $67.2 \pm$ $27.9 \mathrm{ppb}$ during afternoon $(\sim 14: 00 \mathrm{hr})$, remained more or less steady until $\sim 17: 00 \mathrm{hr}$, and then decreased until next morning. The diurnal pattern of $\mathrm{NO}$ and $\mathrm{NO}_{2}$ was characterized by two peaks; morning and evening peak. The morning peak of $\mathrm{NO}(1.5 \mathrm{ppb})$ was observed at around 7:00 $\mathrm{hr}$ and that of $\mathrm{NO}_{2}(11.0 \mathrm{ppb})$ appeared $1 \mathrm{hr}$ after NO peak. The evening peaks of NO (1.0 ppb) and $\mathrm{NO}_{2}$ (12.3 ppb) were observed around 22:00 hr. High levels of primary precursors ( $\mathrm{NO}$ and $\mathrm{NO}_{2}$ ) during late evening hours are a combination of anthropogenic emissions, boundary layer processes, chemical reactions and local surface wind pattern. During night hours the boundary layer descends and pollutants released from anthropogenic sources get trapped in shallow boundary layer results in peak concentration around 21:00-23:00 hr. Both $\mathrm{NO}$ and $\mathrm{NO}_{2}$ showed low concentrations during the daytime. Similar variation in diurnal pattern was also reported by earlier studies in India, at urban sites of Ahmedabad (Lal et al. 2000) and Hyderabad (Swamy et al. 2012); at the rural site of Anantapur (Reddy et al. 2012); and at the semi-urban site of Dibrugarh (Bhuyan et al. 2014).

\subsection{Seasonal variation of $\mathrm{O}_{3}$ and $\mathrm{NO}_{2}$}

Figure 4 shows a well-defined seasonal variation of $\mathrm{O}_{3}$ and $\mathrm{NO}_{2}$ on the diurnal scale. In all the seasons, the diurnal variation pattern of ozone followed almost the same pattern; however, the amplitudes of variation were different; with the highest amplitude in the summer $(79.7 \pm 15.9 \mathrm{ppb})$, followed by post-monsoon $(73.0 \pm 9.5 \mathrm{ppb})$, winter $(58.9 \pm$ $20.5 \mathrm{ppb})$ and lowest in monsoon $(32.0 \pm 5.1 \mathrm{ppb})$ season. High level in summer season was attributed to high temperature; low relative humidity and intense solar radiation which favour photochemical generation of $\mathrm{O}_{3}$ (figure $2 \mathrm{a}-\mathrm{c}$ ). PBL height was also high in the summer season, which allows the $\mathrm{O}_{3}$ rich upper tropospheric air to percolate 

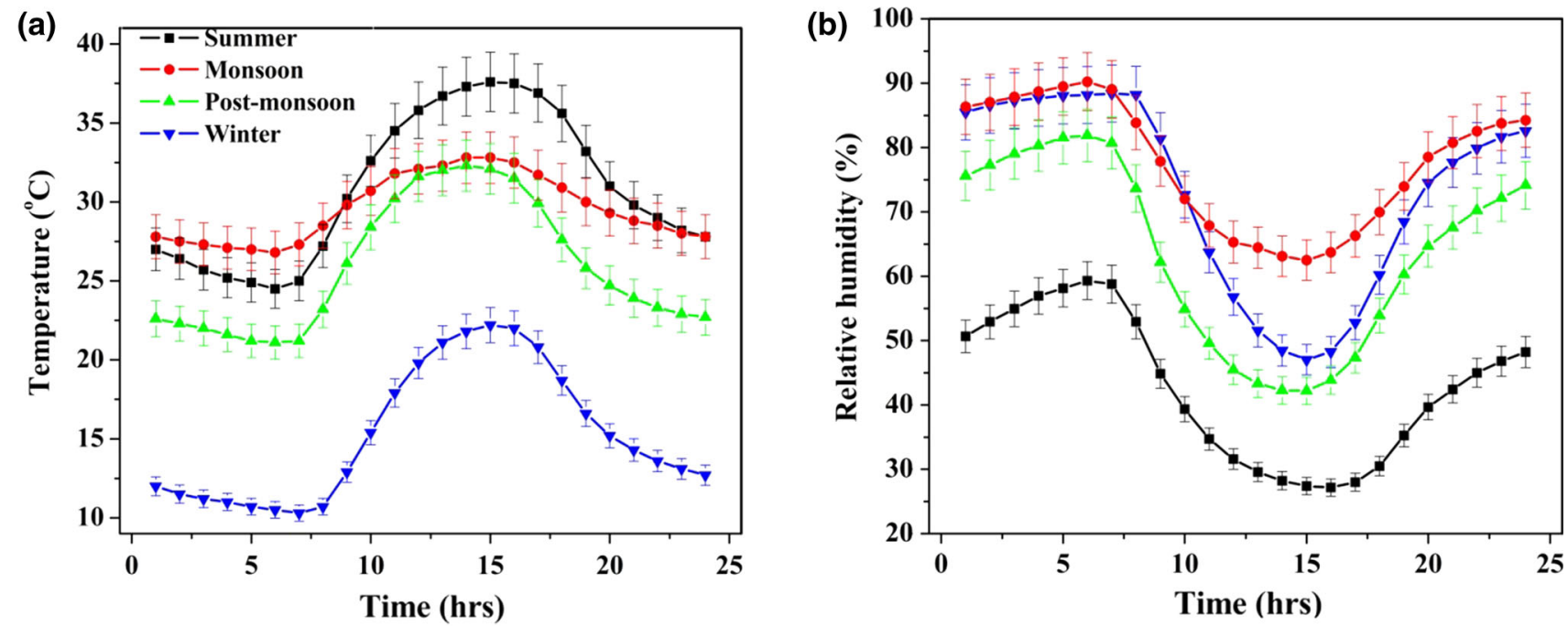

(c)

(d)
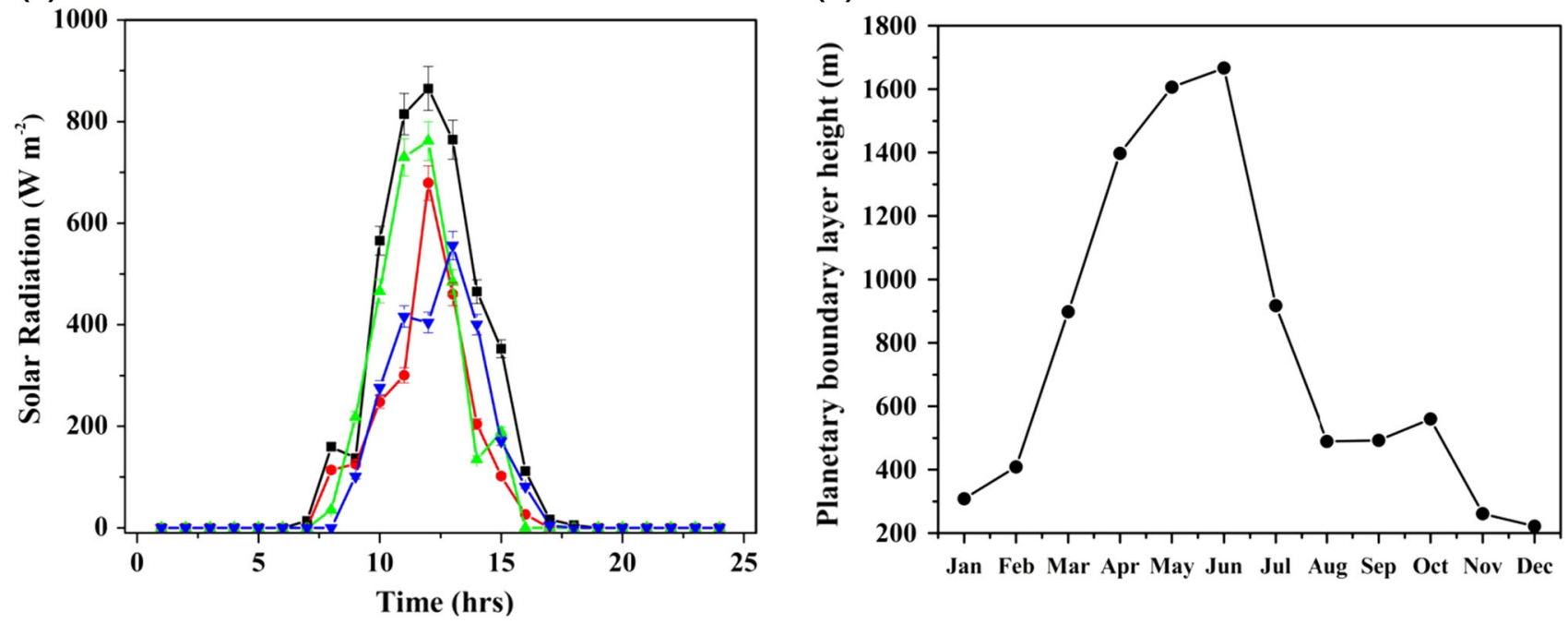

Figure 2. Diurnal variation of (a) temperature, (b) relative humidity, (c) solar radiation in summer, monsoon, post-monsoon and winter and (d) monthly variation of planetary boundary layer height.

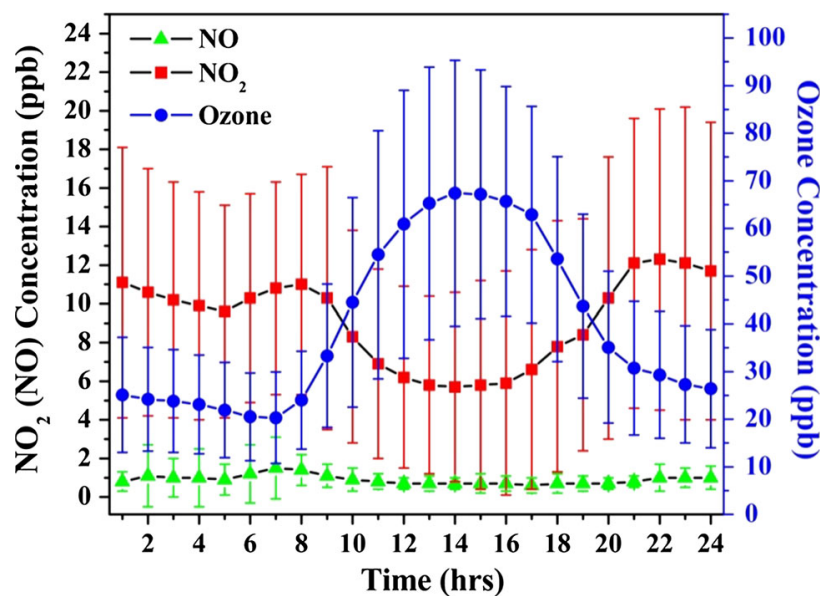

Figure 3. Average diurnal variation of $\mathrm{NO}, \mathrm{NO}_{2}$ and surface $\mathrm{O}_{3}$ at the study site. downward and enhance the $\mathrm{O}_{3}$ concentration near the surface. A similar observation was reported by Bhuyan et al. (2014) at a semi-urban site, Dibrugarh and Putero et al. (2014) at the global WMO/GAW station Nepal Climate ObservatoryPyramid (NCO-P, $5079 \mathrm{~m}$ a.s.l.) in the southern Himalayas. Stratospheric intrusions may result in the rise in upper tropospheric ozone (Sandhya et al. 2015). During the monsoon season, washout of precursors may lead to lowest concentration of $\mathrm{O}_{3}$. Low levels of ozone and $\mathrm{NO}_{\mathrm{x}}$ in monsoon season may be attributed to high humidity $\left(\mathrm{O}_{3}\right.$ vs. $\mathrm{RH}$, $r=-0.63 ; p<0.001$ ) and wet scavenging of ozone and its precursors due to heavy rainfall. At the study site, $97 \%$ rainfall was observed in monsoon season; in addition, continuous rainfall for two to 

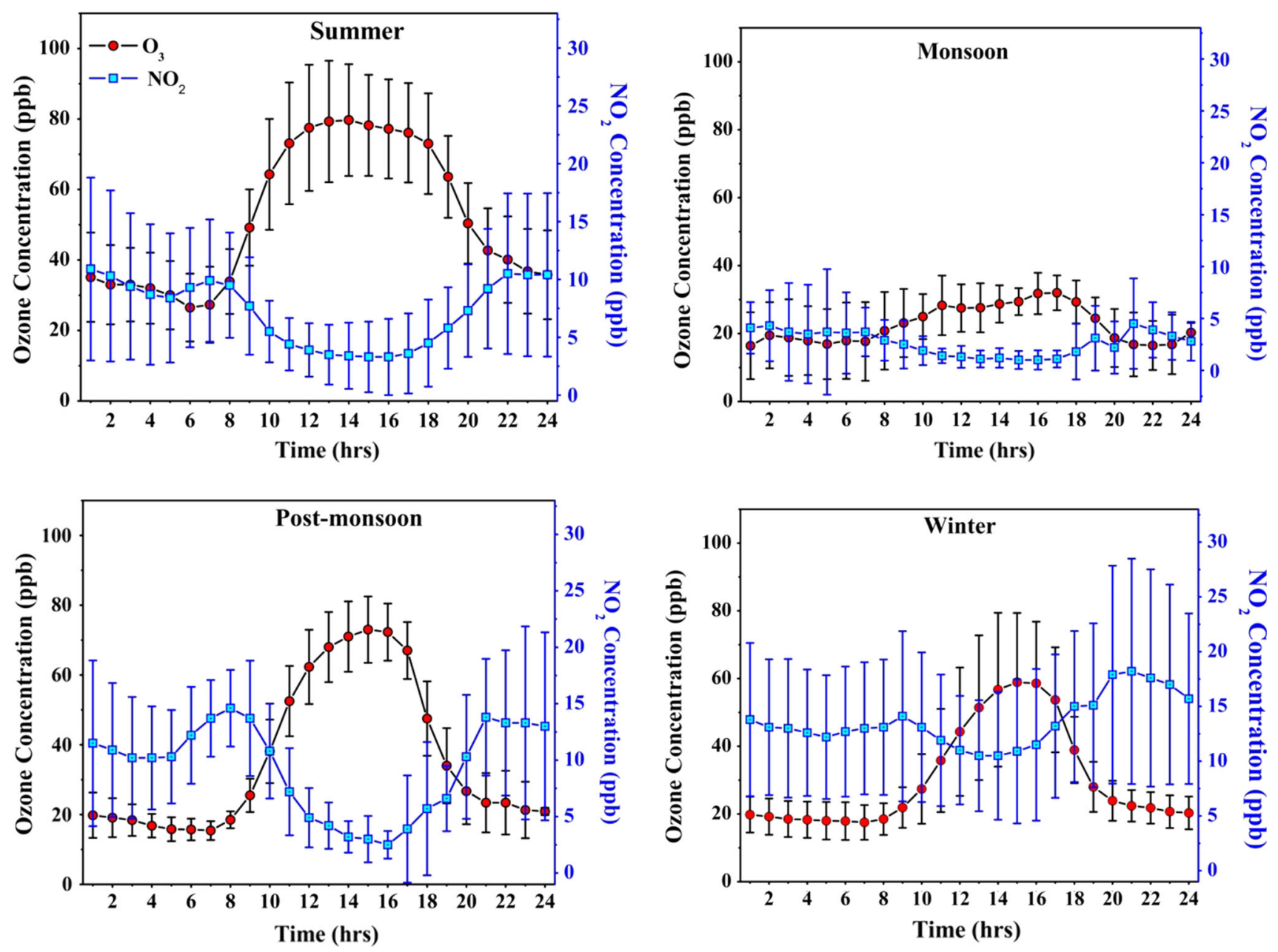

Figure 4. Diurnal variations of $\mathrm{O}_{3}$ and $\mathrm{NO}_{2}$ in different seasons.

three days was also observed which lead to trace gas levels below the detection limit. High water content in air may lead to the removal of nitrogen oxides from air to form nitric and nitrous acid because of their high water solubility (Seinfeld and Pandis 2006). Earlier studies have also reported a decrease in $\mathrm{O}_{3}, \mathrm{NO}, \mathrm{NO}_{2}$ and $\mathrm{NO}_{\mathrm{x}}$ levels due to rainfall (Reddy et al. 2012; Bhuyan et al. 2014; Sharma et al. 2016). In addition, during monsoon season the wind direction was predominantly from Arabian Sea in south-west direction; therefore, these air-masses were comparatively clean in nature. However, in other seasons, the dominant wind direction was north, northwest when air-masses passed through industrial and urban locations. At the rural site of Gadanki (Renuka et al. 2014) although $\mathrm{NO}_{\mathrm{x}}$ levels were very low throughout the year yet ozone levels were reasonably distinct which may be attributed to high levels of VOCs (isoprene and monoterpenes). However, as the present site is $\mathrm{NO}_{\mathrm{x}}$-sensitive, therefore, even the slight decrease in $\mathrm{NO}_{\mathrm{x}}$ may result in the decrease in ozone levels. The diurnal cycle of $\mathrm{O}_{3}$ and solar radiations followed the same pattern (figures 2c and 4). Solar radiations peak at around 12:00 $\mathrm{hr}$ in all the seasons [summer $\left(865 \mathrm{Wm}^{-2}\right)$, monsoon $\left(679 \mathrm{~W} \mathrm{~m}^{-2}\right)$ and post-monsoon $\left(762 \mathrm{~W} \mathrm{~m}^{-2}\right)$ ] except in winter $\left(556 \mathrm{Wm}^{-2}\right)$ season. However, peak $\mathrm{O}_{3}$ concentration was observed around 13:00-16:00 hr.

$\mathrm{NO}_{2}$ attained the highest levels during winter $(18.2 \pm 10.3 \mathrm{ppb})$ season followed by post-monsoon $(14.6 \pm 3.4 \mathrm{ppb})$, summer $(10.9 \pm 7.9 \mathrm{ppb})$ and lowest in monsoon $(4.5 \pm 4.4 \mathrm{ppb})$ season. During winter, $\mathrm{NO}_{2}$ released from primary sources gets trapped near the surface due to low PBL height resulting in high levels of $\mathrm{NO}_{2}$. Low levels in summer months may be due to: (i) dilution of pollutants due to high PBL and (ii) greater photochemical loss due to intense solar radiation.

An analysis of diurnal and seasonal variation of ozone levels at different sites in India was done to elucidate the effect of meteorological parameters 
Table 1. Comparison of monthly average maximum and minimum surface ozone (ppb) with other sites in India.

\begin{tabular}{llll}
\hline & \multicolumn{1}{c}{ Site } & $\begin{array}{c}\text { Monthly average minimum } \\
\text { and maximum }(\mathrm{ppb})\end{array}$ & \multicolumn{1}{c}{ References } \\
\hline Trivandrum & Coastal & $11.5 \pm 4.7$ to $28.1 \pm 16.2$ & David and Nair $(2011)$ \\
Pantnagar & Sub-urban & $10.8 \pm 12.1$ to $39.3 \pm 18.9$ & Ojha et al. $(2012)$ \\
Nainital & High-altitude & $22.8 \pm 7.4$ to $62.0 \pm 12.0$ & Sarangi et al. $(2014)$ \\
Anantapur & Rural & 16.5 to 55.7 & Gopal et al. $(2014)$ \\
Gadanki & Rural & 9.0 to 37.0 & Renuka et al. $(2014)$ \\
Ahmedabad & Urban & 18.1 to 35 & Mallik et al. $(2015)$ \\
Udaipur & Urban & 17.4 to 32.0 & Yadav et al. $(2016)$ \\
Delhi & Urban & $16.8 \pm 6.0$ to $40.3 \pm 8.7$ & Sharma et al. $(2016)$ \\
Varanasi & Urban & $22.0 \pm 6.9$ to $63.9 \pm 13.7$ & Shukla et al. $(2017)^{*}$ \\
Lucknow & Urban & $14.9 \pm 1.3^{\#}$ to $52.4 \pm 53.5^{\#}$ & Shukla et al. $(2017)^{*}$ \\
Agra & Sub-urban & $14.0 \pm 9.2$ to $57.6 \pm 25.5$ & Present study \\
\hline
\end{tabular}

*Averages in $\mu \mathrm{gm}^{-3}$.

\# Minimum is average for Nov.-Dec.; maximum is average for Jan.-Feb.

and precursors (table 1). At the present site, diurnal variation of ozone was characterized high levels during noon and afternoon hours, and seasonal maxima was observed in summer season while minima in monsoon. However, at other sites in India, ozone followed different diurnal and seasonal variations. At the high altitude site in Nainital (Sarangi et al. 2014), highest monthly mean $(62 \pm 12 \mathrm{ppb})$ was observed in spring season, while lowest in the summer-monsoon season. Diurnal variation is not seen at this high altitude site as ozone levels are influenced by wind flow and PBL height rather than photochemistry. At the rural site Gadanki, the diurnal trend of ozone was almost same as the present site, but ozone and $\mathrm{NO}_{\mathrm{x}}$ levels were lower than present site because Gadanki is not affected by vehicular emissions. At the coastal site of Trivandrum, the broad daytime peak of ozone may be attributed to the strong influence of sea and land breeze. At the urban site of Delhi, although monthly average ozone was lower, $\mathrm{NO}_{\mathrm{x}}$ levels were very high as compared to the present site (Sharma et al. 2016). Similar variation was observed at the urban sites of Lucknow and Varanasi where monthly average $\mathrm{O}_{3}$ concentrations were lower than the present site, however, at Lucknow $\mathrm{NO}_{\mathrm{x}}$ levels were comparatively high and at Varanasi, they were comparable to the present site (Shukla et al. 2017). Earlier studies have also reported low levels of $\mathrm{NO}, \mathrm{NO}_{2}$ and $\mathrm{NO}_{\mathrm{x}}$, and high levels of ozone at sub-urban sites as compared to urban sites (Kulkarni et al. 2016) as the high levels of $\mathrm{NO}_{\mathrm{x}}$ are released from vehicular sources (containing high levels of NO) leading the destruction of ozone. The monthly average minimum and
Table 2. Rate of change of ozone in different months.

\begin{tabular}{|c|c|c|}
\hline Month & $\begin{array}{c}\text { Positive rate } \\
\text { of change at } \\
08: 00-11: 00 \mathrm{hr} \\
\quad(\mathrm{ppb} / \mathrm{hr})\end{array}$ & $\begin{array}{c}\text { Negative rate } \\
\text { of change at } \\
17: 00-19: 00 \mathrm{hr} \\
(\mathrm{ppb} / \mathrm{hr})\end{array}$ \\
\hline Jan & 2.9 & -9.1 \\
\hline Feb & 1.7 & -6.6 \\
\hline Mar & 13.8 & -7.2 \\
\hline Apr & 16.3 & -7.7 \\
\hline May & 15.5 & -7.7 \\
\hline Jun & 6.3 & -3.6 \\
\hline Jul & 4.0 & -1.1 \\
\hline Aug & 1.1 & -1.4 \\
\hline Sep & 8.2 & -7.8 \\
\hline Oct & 9.1 & -8.3 \\
\hline Nov & 10.8 & -11.6 \\
\hline Dec & 6.1 & -13.2 \\
\hline
\end{tabular}

maximum of $\mathrm{O}_{3}$ at the present site were higher than the levels at a sub-urban site of Pantnagar (Ojha et al. 2012) and comparable to the levels at a rural site of Anantapur (Gopal et al. 2014).

\subsection{Rate of change of Ozone}

The rate of change of $\mathrm{O}_{3}$ defines the formation or destruction of $\mathrm{O}_{3}$ in unit time. Table 2 shows the monthly variation of the rate of change of ozone $\left[\mathrm{d}\left(\mathrm{O}_{3}\right) / \mathrm{dt}\right]$ in the morning (08:00-11:00 hr IST) and in the evening hours (17:00-19:00 hr IST). The slope of the regression line corresponds to the rate of change of $\mathrm{O}_{3}$ concentration. The positive rate of change corresponds 
Table 3. Comparison of Rate of change of $\mathrm{O}_{3}$ with other sites in India.

\begin{tabular}{lccl}
\hline & $\begin{array}{c}\text { Rate of change } \\
\text { at 08:00-11:00 hr } \\
(\mathrm{ppb} / \mathrm{hr})\end{array}$ & $\begin{array}{c}\text { Rate of change } \\
\text { at:00-19:00hr } \\
(\mathrm{ppb} / \mathrm{hr})\end{array}$ & \multicolumn{1}{c}{ References } \\
\hline $\begin{array}{l}\text { Site } \\
\quad \text { (sub-urban site) }\end{array}$ & 7.9 & -6.9 & Present study \\
$\begin{array}{l}\text { Mohal (sub-urban } \\
\text { valley site) }\end{array}$ & 7.3 & -5.9 & Sharma et al. $(2013)$ \\
$\begin{array}{l}\text { Anantapur (rural site) } \\
\text { Delhi (urban site) } \\
\text { Ahmedabad (urban } \\
\text { site) }\end{array}$ & 4.1 & -3.0 & Reddy et al. $(2008)$ \\
& 4.5 & -5.3 & $\begin{array}{c}\text { Ahammed } \text { et al. }(2006) \\
\text { Lal } \text { et al. }(2000)\end{array}$ \\
\hline
\end{tabular}

to the $\mathrm{O}_{3}$ formation, while the negative rate of change corresponds to $\mathrm{O}_{3}$ loss rate. The average positive rate of change of $\mathrm{O}_{3}$ was maximum in April (16.3 ppb/hr) and minimum in August (1.1 ppb/hr). Maximum production rate in April may be due to meteorological conditions which favour photochemical generation of $\mathrm{O}_{3}$, while the minimum value in August may be due to greater cloud cover resulting in lower photochemical activity and scavenging of its precursors $\left(\mathrm{NO}_{2}\right.$ and NO) through rainfall. The average negative rate of change of $\mathrm{O}_{3}$ was maximum in December $(-13.2$ $\mathrm{ppb} / \mathrm{hr})$ while minimum in July $(-1.1 \mathrm{ppb} / \mathrm{hr})$. In table 2, sharp increase in the rate of ozone formation was observed from February to March, however, the rate of destruction was gradual. Ozone formation is a complex process which gets influenced by number of factors, the drastic change in ozone formation rate may be attributed to (i) sharp increase in average temperature during 08:00 - 11:00 hr from February $\left(14.4^{\circ} \mathrm{C}\right)$ to March $\left(24.5^{\circ} \mathrm{C}\right)$, however, during 17:00-19:00 hr, no distinct variation was observed (February, $23.6^{\circ} \mathrm{C}$; March, $25.7^{\circ} \mathrm{C}$ ), (ii) although, there was no significant difference in solar intensity, the duration of solar radiation was increased by 5 hrs in March, (iii) wind speed was high in February as compared to March, (iv) humidity was also high in February $(\mathrm{RH}=73 \%)$ as compared to March $(\mathrm{RH}=50 \%),(\mathrm{v})$ difference in morning and evening hours PBL height was also high in March, (vi) in addition, February month had 8-9 cloudy days and rainfall was also observed. Wind direction was same in both the months (west, northwest). A sharp change in the rate of ozone formation and destruction was also observed from August to September. Although there was no significant change in average temperature during 08:00-11:00 hr and 17:00-19:00 hr from August to September, change in relative humidity was significant during 08:00-11:00 hr (in August $\mathrm{RH}=80 \%$ and in September $\mathrm{RH}=68 \%$ ) and 17:00-19:00 hr (in August $\mathrm{RH}=74 \%$ and in September $\mathrm{RH}=$ $60 \%$ ). In addition, in August, frequent rainfall may result in low levels of ozone and its precursors due to wet scavenging. On the days of rainfall, the levels of ozone, $\mathrm{NO}$ and $\mathrm{NO}_{2}$ were very low and sometimes below the detection limit. In August, 16-17 days rainfall was observed, in contrast to September when rain occurred only on $2-3$ days.

Table 3 shows a comparison of the rate of change of $\mathrm{O}_{3}$ at the present site with different sites in India. The average rate of change of $\mathrm{O}_{3}(-6.9 \mathrm{ppb} / \mathrm{hr})$ during evening hours was lower than their respective production rate $(7.9 \mathrm{ppb} / \mathrm{hr})$ during morning hours. Similar observations were also reported at rural and other sub-urban sites of India (Reddy et al. 2008; Sharma et al. 2013). At urban sites, Ahmedabad and Delhi, the average negative rate of change during evening hours was higher as compared to the average positive rate of change during morning hours (Lal et al. 2000; Ahammed et al. 2006). According to Naja and Lal (2002), the higher loss rate at urban sites was attributed to the higher production rate of $\mathrm{NO}_{\mathrm{x}}$ from vehicular emissions and fast titration of $\mathrm{O}_{3}$ in the evening hours.

\subsection{Ozone-VOC-NOx sensitivity}

Several photochemical indicators $\left(\mathrm{H}_{2} \mathrm{O}_{2} / \mathrm{HNO}_{3}\right.$, $\mathrm{O}_{3} / \mathrm{HNO}_{3}, \mathrm{O}_{3} / \mathrm{NO}_{\mathrm{y}}$ ) have been used in earlier studies to assess $\mathrm{O}_{3}-\mathrm{NO}_{\mathrm{x}}-$ VOC sensitivity (Sillman et al. 1997; Peng et al. 2011). In the present study, the $\mathrm{O}_{3} / \mathrm{HNO}_{3}$ ratio was used as an 


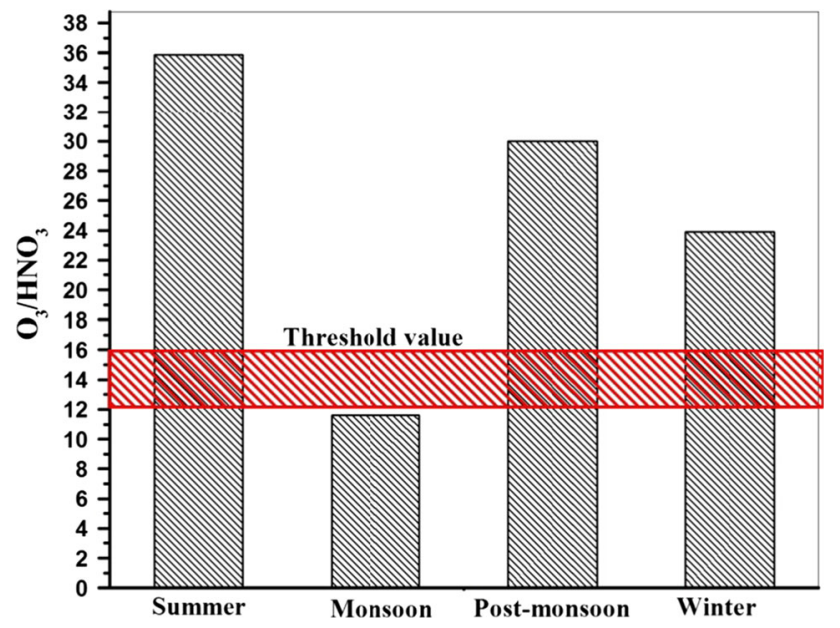

Figure 5. Seasonal variation of $\mathrm{O}_{3} / \mathrm{HNO}_{3}$ ratio.

indicator to assess $\mathrm{O}_{3}-\mathrm{NO}_{\mathrm{x}}-\mathrm{VOC}$ sensitivity. Sillman (1995) reported that the formation of ozone is VOC-sensitive when the $\mathrm{O}_{3} / \mathrm{HNO}_{3}$ is below the threshold value $(12-16)$ and this value is true for a moderately polluted environment (Sillman et al. 1998; Sillman and He 2002).

During the study period, $\mathrm{HNO}_{3}$ concentration ranged from 0.3 to $7.0 \mathrm{ppb}$ with average concentration $2.3 \pm 1.8 \mathrm{ppb}$ while $\mathrm{O}_{3} / \mathrm{HNO}_{3}$ ratio ranged from 6.0 to 118.2 . Figure 5 shows that the $\mathrm{O}_{3} / \mathrm{HNO}_{3}$ ratio was above the threshold value in summer, post-monsoon and winter indicating the present site is $\mathrm{NO}_{\mathrm{x}}$-sensitive for most of the time in summer $(73 \%)$, post-monsoon $(70 \%)$ and winter $(50 \%)$. The wet removal of $\mathrm{O}_{3}$ and $\mathrm{HNO}_{3}$ through rainfall in monsoon may be responsible for decrease in $\mathrm{O}_{3} / \mathrm{HNO}_{3}$ ratio; however, the site is predominantly $\mathrm{NO}_{\mathrm{x}}$ sensitive.

\subsection{Ozone episode analysis}

High temperature and intense solar radiation favour photochemical generation of ozone (Tu et al. 2007; Shan et al. 2009). At the present site, the summer season is associated with high temperature (avg. $31^{\circ} \mathrm{C}$ ), long sunshine duration $(8-9 \mathrm{hr}$ ) and low relative humidity (avg. 43\%). These conditions may lead to days with high $\mathrm{O}_{3}$ levels, which may be considered as ozone episodes. The most common criteria to identify high ozone episodes are when ozone exceeds air quality standard of environmental agencies at a particular site. Therefore, high ozone episodes were identified when hourly ozone concentration exceeded $90 \mathrm{ppb}$ (NAAQS for India, CPCB 2009). These episodes may be influenced by local photochemistry as well as transport.
One such episodic event was observed, from 6th to 10th May (figure 6). On 5th May, although episodic levels of ozone were not observed, but high levels were observed during night time (45$60 \mathrm{ppb}$ ). On 6th May, highest levels (102.8 ppb) of ozone were observed at 14:00 hr when wind speed was low (below $2 \mathrm{~m} / \mathrm{s}$ ). Further on 6th May, high levels of ozone were also observed during late night hours (above $50 \mathrm{ppb}$ ) when $\mathrm{NO}_{\mathrm{x}}$ levels and wind speed were also high $(4-5 \mathrm{~m} / \mathrm{s})$. The high levels of ozone during the daytime may be due to local photochemistry and transport; however, night time high levels may be solely due to transport. On 7th May, peak ozone levels were observed at 13:00 $\mathrm{hr}(106.5 \mathrm{ppb})$ and high levels of ozone were observed till 21:00 hr (67 ppb). During this episode, wind speed was high $(4-5 \mathrm{~m} / \mathrm{s})$. On 8 th May, peak ozone levels were observed at 12:00 hr (124 ppb), night time levels were low and $\mathrm{NO}_{\mathrm{x}}$ levels were slightly higher than consecutive days. Wind speed was moderate during peak ozone hours $(2-3 \mathrm{~m} / \mathrm{s})$. Similar variation was observed on 9 th and 10th May with peak ozone values of 118.2 and $112 \mathrm{ppb}$, respectively. During all episodic days, the temperature was high and maximum temperature ranged from 43 to $45^{\circ} \mathrm{C}$. Relative humidity was low and duration of solar radiation was 7-8 hrs. 11th May was a normal day when peak ozone levels decreased to $78 \mathrm{ppb}$ with a simultaneous decrease in $\mathrm{NO}_{\mathrm{x}}$ levels. On this day, a decrease in maximum temperature and an increase in $\mathrm{RH}$ and wind speed $(3.5-6.5 \mathrm{~m} / \mathrm{s})$ were observed. During the month of May, wind speed varied between 0 and $6.5 \mathrm{~m} / \mathrm{s}$ and high levels of ozone were associated when wind speed ranged from 2 to $5 \mathrm{~m} / \mathrm{s}$. Vertical profile of ozone (MERRA 5.2.0, https://giovanni. sci.gsfc.nasa.gov/giovanni/) from 975 to $500 \mathrm{hPa}$ also showed high levels on 7 th and 8th May as compared to consecutive days. However, all the trajectories during the episodic event were within boundary layer and potential vorticity (https:// giovanni.sci.gsfc.nasa.gov/giovanni/) was less than $1.2 \mathrm{PV}\left(1 \mathrm{PV}=10^{-6} \mathrm{~m}^{2} \mathrm{~s}^{-1} \mathrm{Kkg}^{-1}\right)$ at all pressure levels $(300-800 \mathrm{hPa})$, which suggest no vertical transport during the event. Earlier studies have suggested that potential vorticity (PV) greater than 1.5 PV in the troposphere is an indicator of stratospheric subsidence (Lai et al. 2011).

Air-mass trajectory analysis of $25 \%$ of days with high ozone and $25 \%$ of normal days was performed to elucidate the effect of wind pattern during the episodic event. The analysis was done using Geographical Information System (GIS) based 

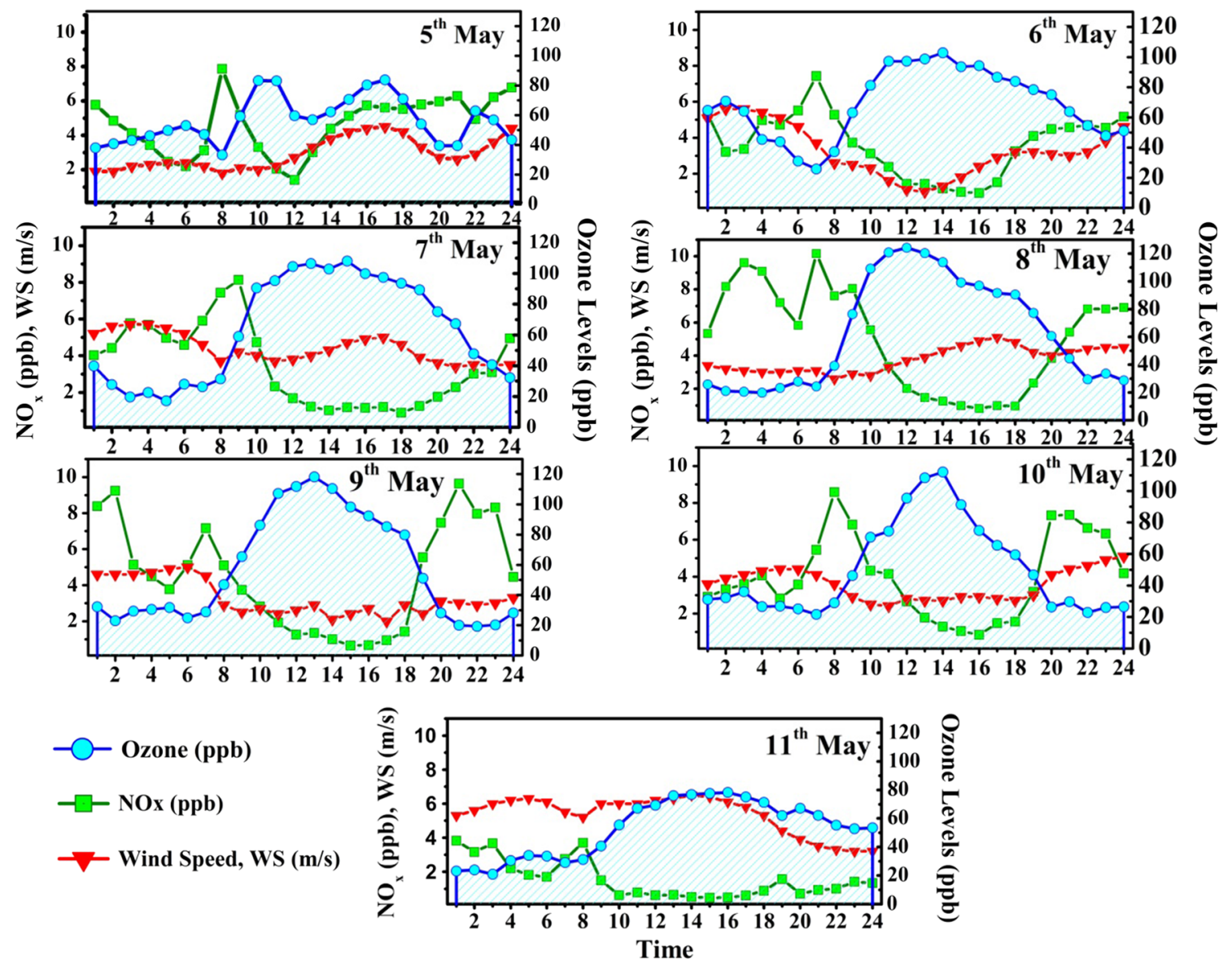

Figure 6. Diurnal variation of ozone, $\mathrm{NO}_{\mathrm{x}}$ and wind speed during 5-11 May 2013.

Trajstat software (Wang et al. 2009). The meteorological files for running the model were extracted from GDAS archive at NOAA ARL $\left(0.5 \times 0.5^{\circ}\right) \cdot 123$ episodic days and 168 normal days were identified during May 2012-May 2013. The days when hourly ozone exceeded $90 \mathrm{ppb}$ were considered as episodic days, however, when hourly ozone was below and close to 75 ppb were considered as normal days. Therefore, 31 episodic days and 42 normal days' air-masses are shown in figure $7(\mathrm{a}$ and $\mathrm{b})$. It is evident from the figure that wind directions were quite different during episodic and normal days. During episodic days, most of the air-masses were continental in nature and from north, northwest and central Indian region, however, during normal ozone days, most of the air-masses were marine in origin.

\subsection{Surface ozone and respirable fine particles $\left(P M_{2.5}\right)$}

The average $\mathrm{PM}_{2.5}$ mass concentration was $93.9 \mu \mathrm{g} \mathrm{m}^{-3}$, maximum levels were observed in December $\left(218.6 \mu \mathrm{g} \mathrm{m}^{-3}\right)$, while minimum in July $\left(25.7 \mu \mathrm{g} \mathrm{m}^{-3}\right.$; figure 8a). In most of the months, the mass concentration was above NAAQ (National Ambient Air Quality) standard value, which is $60 \mu \mathrm{g} \mathrm{m}^{-3}$ (CPCB 2009) for $24 \mathrm{hr}$. The elevated levels observed in January (winter season) may be due to additional emission sources (increased biomass, coal and fossil fuel combustion) and stable meteorological conditions, which favour the ambient particles to remain suspended in the atmosphere. In monsoon months, heavy rainfall caused the removal of particulate matter by wet scavenging.

Aerosol can affect $\mathrm{O}_{3}$ concentration because (a) aerosols can absorb or scatter a fraction of solar radiation causing change in photolysis rates, and affect $\mathrm{O}_{3}$ formation (Jacobson 1998; Castro et al. 2001; Li et al. 2011); (b) aerosols can influence the tropospheric trace gas chemistry by providing surface for heterogeneous chemical reactions. Heterogeneous reactions occurring on the aerosols surface may affect trace gases concentrations (Jacob 2000; Xu et al. 2012). Xu et al. (2012) reported that heterogeneous reactions affect $\mathrm{O}_{3}$ formation by (i) disturbing the radical and $\mathrm{NO}_{\mathrm{x}}$ cycles and 
(a)

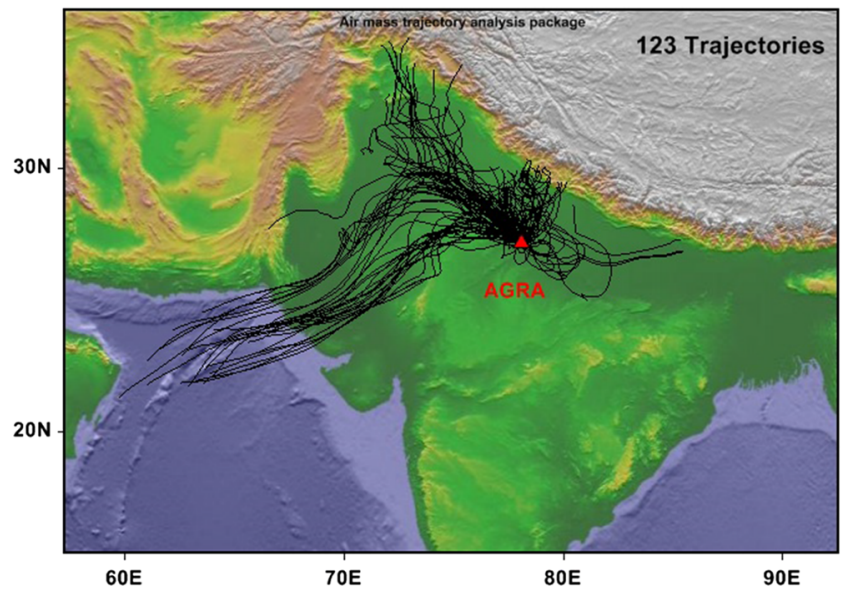

(b)

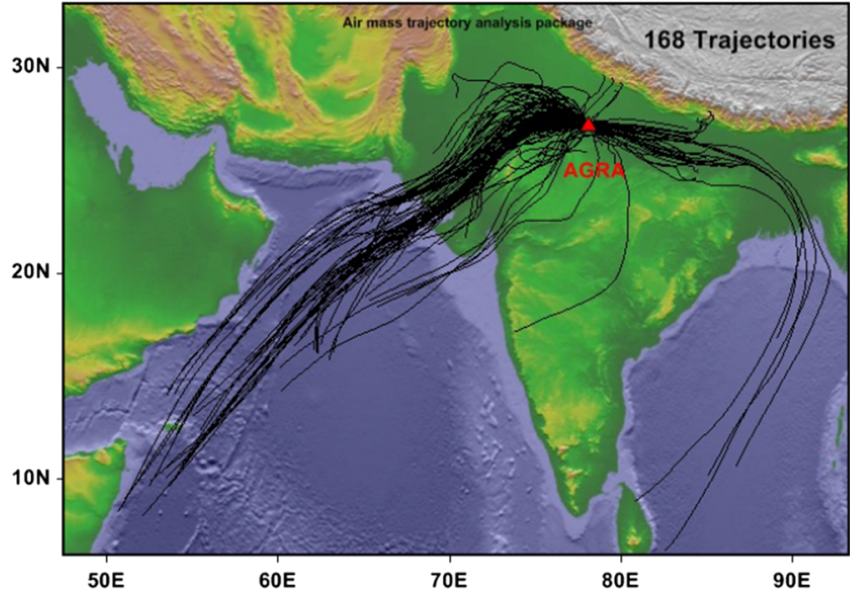

Figure 7. Air mass back trajectories during (a) $25 \%$ of high ozone days and (b) $25 \%$ of normal day.

(a)

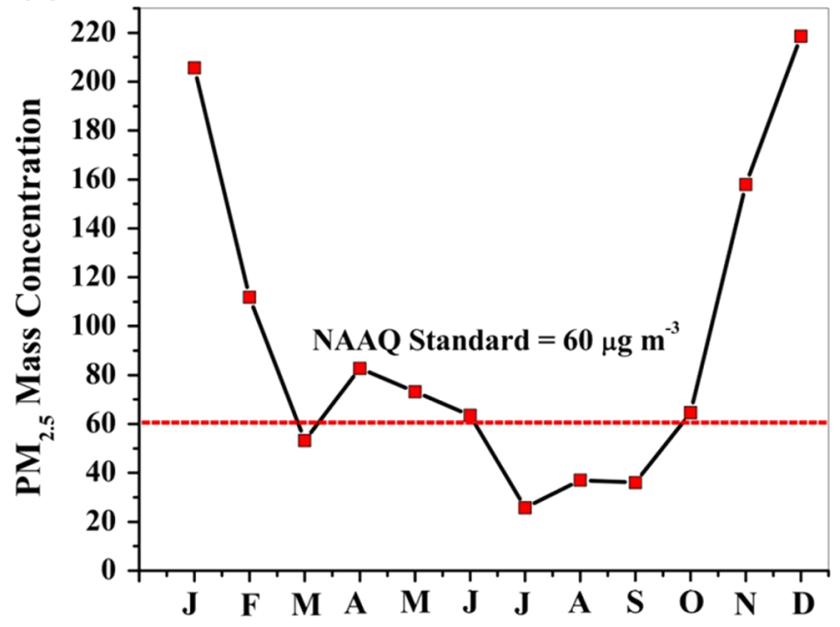

(c)

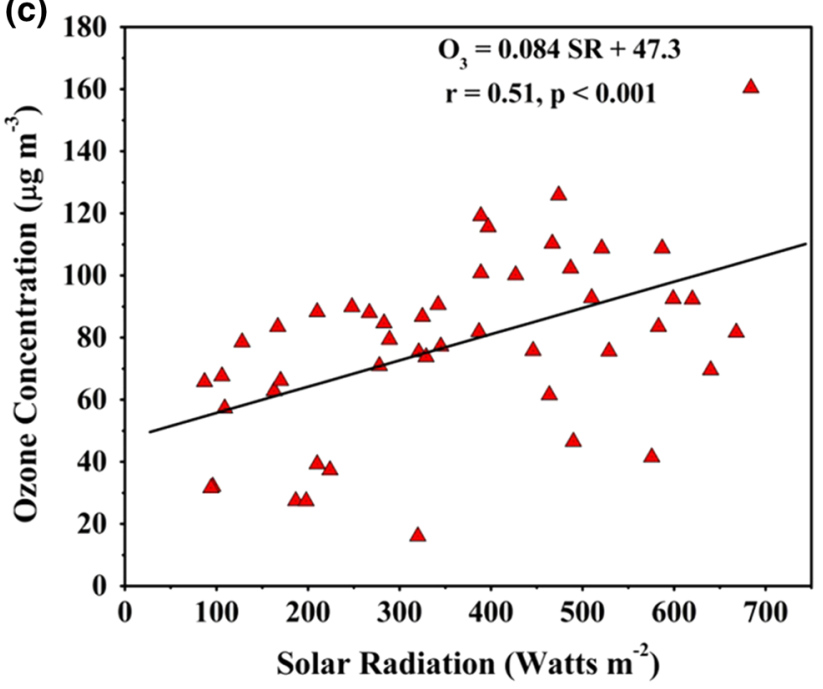

(b)

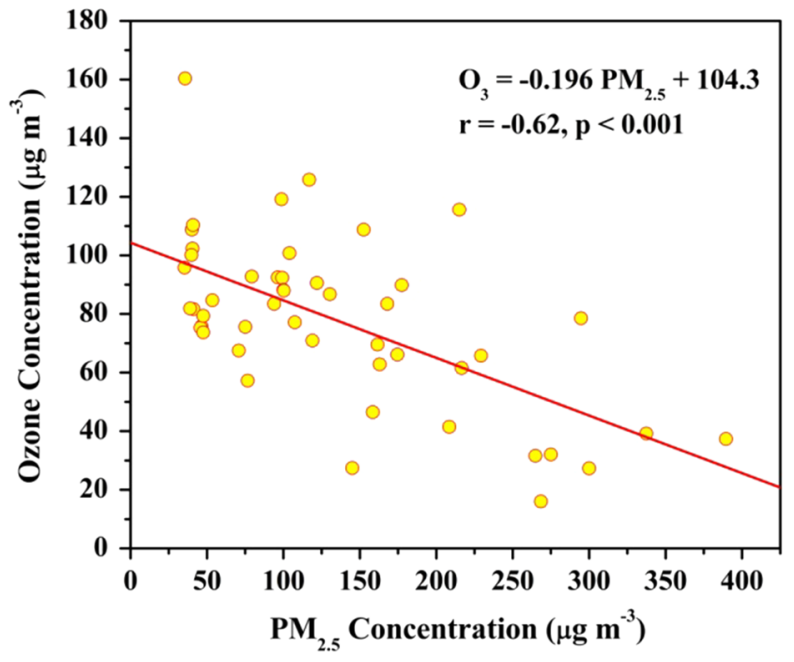

(d)

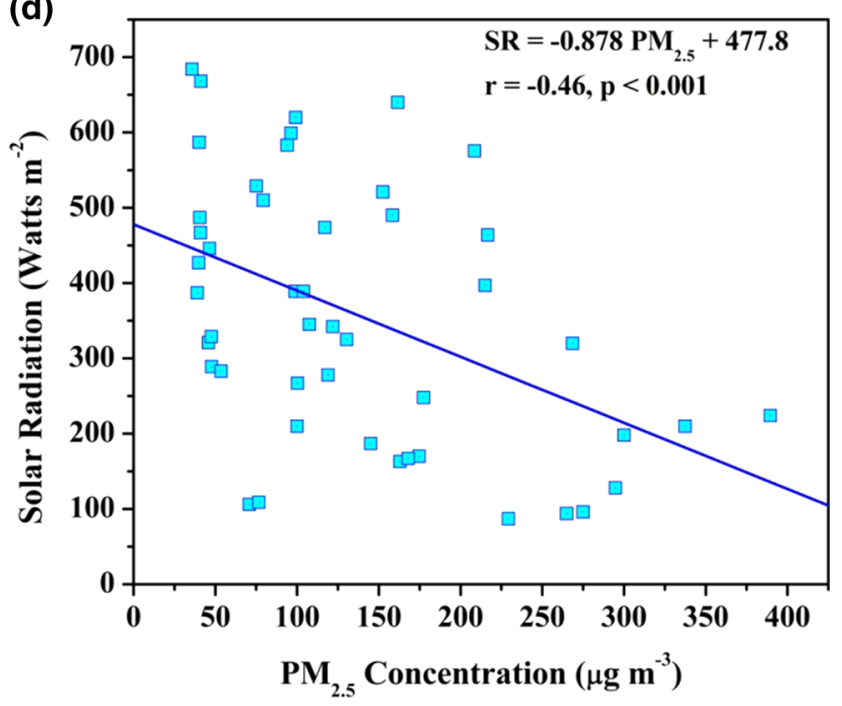

Figure 8. (a) Monthly variation of $\mathrm{PM}_{2.5}$ and regression analysis between (b) $\mathrm{PM}_{2.5}$ and $\mathrm{O}_{3},(\mathbf{c}) \mathrm{O}_{3}$ and solar radiation, and (d) solar radiation and $\mathrm{PM}_{2.5}$. 
(ii) direct removal of $\mathrm{O}_{3}$ by aerosols. Disturbance of radical and $\mathrm{NO}_{\mathrm{x}}$ cycles include heterogeneous reactions with three species namely: $\mathrm{NO}_{2}, \mathrm{~N}_{2} \mathrm{O}_{5}$, and $\mathrm{NO}_{3} . \mathrm{NO}_{2}$ heterogeneous reaction prevails where $\mathrm{NO}_{\mathrm{x}}$ concentration is high and it produces $\mathrm{HONO}$ and $\mathrm{HNO}_{3}$. HONO produces $\mathrm{OH}^{\circ}$ radicals by photolysis and adds more new radicals to the radical cycle. These radicals are responsible for initiation of $\mathrm{O}_{3}$ formation and are predominant in urban areas. However, when $\mathrm{NO}_{\mathrm{x}}$ concentration is low $\left(\mathrm{NO}_{\mathrm{x}}\right.$-sensitive regime as in present site), the three heterogeneous reactions could proceed at a comparable rate, and the $\mathrm{N}_{2} \mathrm{O}_{5}$ heterogeneous reaction could have a relatively large effect on the $\mathrm{NO}_{\mathrm{x}}$ cycle. $\mathrm{HNO}_{3}$ is formed as a result of $\mathrm{N}_{2} \mathrm{O}_{5}$ and $\mathrm{NO}_{3}$ heterogeneous reaction leading to direct removal of $\mathrm{NO}_{\mathrm{x}}$, causing a significant decrease in $\mathrm{O}_{3}$ concentration ( $\mathrm{Xu}$ et al. 2012; figure 9).

Partial Pearson correlation analysis was performed to elucidate the effect of $\mathrm{PM}_{2.5}$ on ozone levels. For the analysis, ozone was considered as a dependent variable, solar radiation (SR) as an independent variable and $\mathrm{PM}_{2.5}$ as a controlling variable. For zero order correlation $\left(\mathrm{PM}_{2.5}\right.$ was not controlling), ozone showed significant positive correlation with $\mathrm{SR}(r=0.52, p<0.001)$ and negative correlation with $\mathrm{PM}_{2.5}(r=-0.65, p<0.001)$, while $\mathrm{PM}_{2.5}$ showed significant negative correlation with SR $(r=-0.46, p<0.001)$. However, the Pearson correlation coefficient between ozone and SR reduced to $r=0.32(p<0.05)$ when $\mathrm{PM}_{2.5}$ act as a control or mediator factor, therefore, in presence of $\mathrm{PM}_{2.5}$ correlation between $\mathrm{SR}$ and ozone is reduced. According to Dickerson et al. (1997),

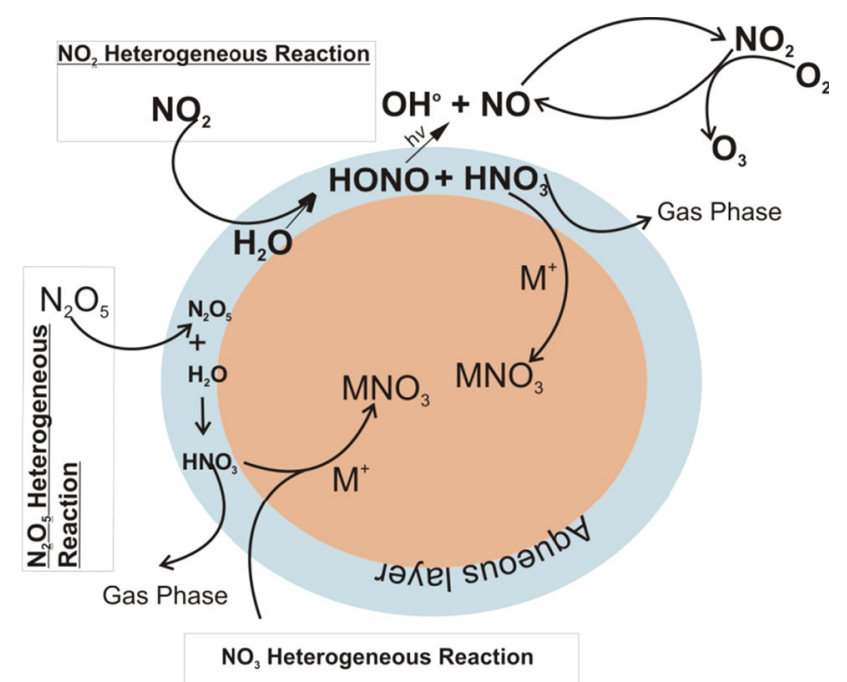

Figure 9. A schematic representation of three heterogeneous reactions at the surface of aerosols. particulate matter of absorptive nature (mineral dust and soot) may reduce UV radiations, and Indian aerosols have high loadings of mineral dust and soot particles (Pipal et al. 2014), therefore, they may lead to decreased ozone levels.

From the regression equations (figure $8 \mathrm{a}-\mathrm{c}$ ), the loss of $\mathrm{O}_{3}$ through $\mathrm{PM}_{2.5}$ due to their effect on SR can be calculated. From equation (1), $10 \mu \mathrm{g} \mathrm{m}^{-3}$ increase in $\mathrm{PM}_{2.5}$ results in the decrease of $1.96 \mathrm{\mu g} \mathrm{m}^{-3}$ of ozone. This decrease involves both decreases in the photochemical formation of ozone (decrease in SR results in the decrease in $\mathrm{O}_{3}$ formation) and loss through heterogeneous reactions. $10 \mathrm{~W} \mathrm{~m}^{-2}$ increase in solar radiation results in $0.84 \mu \mathrm{g} \mathrm{m}^{-3}$ increase in ozone levels (equation 2 ). Similarly, from equation (3), it is evident that $10 \mu \mathrm{g} \mathrm{m}^{-3}$ increase in $\mathrm{PM}_{2.5}$ results in the decrease of $8.78 \mathrm{~W} \mathrm{~m}^{-2}$ of solar radiation, which causes the decrease of $0.74 \mu \mathrm{g} \mathrm{m}^{-3}$ of ozone levels (equations 2 and 3 ). This decrease was due to the decrease in solar radiation caused by $\mathrm{PM}_{2.5}$.

$$
\begin{aligned}
\mathrm{O}_{3} & =-0.196 \mathrm{PM}_{2.5}+104.3 \\
\mathrm{O}_{3} & =0.084 \mathrm{SR}+47.3 \\
\mathrm{SR} & =-0.878 \mathrm{PM}_{2.5}+477.8
\end{aligned}
$$

However, as the total decrease of ozone due to $\mathrm{PM}_{2.5}$ was $1.96 \mu \mathrm{g} \mathrm{m}^{-3}$, therefore, $1.22 \mu \mathrm{g} \mathrm{m}^{-3}$ decrease may be due to heterogeneous reactions (after subtracting loss through decrease in SR from total loss).

\section{Conclusions}

The study investigates the complex chemistry of surface $\mathrm{O}_{3}$ and $\mathrm{NO}_{2}$ at a sub-urban site, Dayalbagh, Agra for the period May 2012-May 2013. The salient points of the study are as follows:

- The diurnal variation was characterized by minimum $\mathrm{O}_{3}$ concentration during the early morning or night hours $(20.3 \pm 9.6 \mathrm{ppb})$ and maximum value at around noontime $(67.2 \pm 27.9 \mathrm{ppb})$ coinciding with intense solar radiation.

- $\mathrm{O}_{3}$ showed a distinct seasonal variation on the diurnal scale with the highest amplitude in summer $(79.7 \pm 15.9 \mathrm{ppb})$, followed by post-monsoon $(73.0 \pm 9.5 \mathrm{ppb})$, winter $(58.9 \pm 20.5 \mathrm{ppb})$ and lowest in monsoon $(32.0 \pm 5.1 \mathrm{ppb})$. High levels in summer season were mainly attributed to intense solar radiation and high temperature, which favour photochemical generation of $\mathrm{O}_{3}$. 
- The positive rate of change of $\mathrm{O}_{3}$ was maximum in April (16.3 ppb/hr), while minimum in August $(1.1 \mathrm{ppb} / \mathrm{hr})$, the negative rate of change of $\mathrm{O}_{3}$ was maximum in December $(-13.2 \mathrm{ppb} / \mathrm{hr})$ and minimum in July $(-1.1 \mathrm{ppb} / \mathrm{hr})$. The average rate of change of $\mathrm{O}_{3}(-6.9 \mathrm{ppb} / \mathrm{hr})$ during evening hours was lower than their respective production rate $(7.9 \mathrm{ppb} / \mathrm{hr})$ during morning hours. This has been attributed to slower titration of ozone by NO during the late evening.

- The $\mathrm{O}_{3} / \mathrm{HNO}_{3}$ ratio was used an indicator to assess $\mathrm{O}_{3}-\mathrm{NO}_{\mathrm{x}}-\mathrm{VOC}$ sensitivity. This value is above the threshold value in summer, postmonsoon and winter indicating the present site was $\mathrm{NO}_{\mathrm{x}}$ sensitive.

- A high ozone episode was observed during 610 May, 2013 which was attributed to photochemistry and transport using meteorological parameters.

- Loss of ozone through $\mathrm{PM}_{2.5}$ was calculated using regression analysis and it was estimated that $10 \mu \mathrm{g} \mathrm{m}^{-3}$ increase in $\mathrm{PM}_{2.5}$ results in decrease of $0.74 \mu \mathrm{g} \mathrm{m}^{-3}$ ozone through reduction in solar radiation and $1.22 \mu \mathrm{g} \mathrm{m}^{-3}$ of ozone through heterogeneous reactions.

\section{Acknowledgements}

The authors are thankful to the Director, Dayalbagh Educational Institute, Agra and the Head, Department of Chemistry for necessary help. The authors gratefully acknowledge the financial support for this work, which is provided by ISRO GBP under AT-CTM project. One of the authors, Nidhi Verma is grateful to the above project for providing SRF.

\section{References}

Ahammed Y N, Reddy R R, Gopal K R, Narasimhulu K, Basha D B, Reddy L S S and Rao T V R 2006 Seasonal variation of surface ozone and its precursor gases during 2001-2003, measured at Anantapur $\left(14.62^{\circ} \mathrm{N}\right)$, a semi-arid site in India; Atmos. Res. 80 151-164.

Aneja V P, Kim D and Chameides W L 1997 Trends and analysis of ambient $\mathrm{NO}, \mathrm{NO}_{\mathrm{y}}, \mathrm{CO}$, and ozone concentrations in Raleigh, North Carolina; Chemosphere 34 611623, https://doi.org/10.1016/S0045-6535(96)00393-1.

Beevers S D, Westmoreland E, Jong M C, Williams M L and Carslaw D C 2012 Trends in $\mathrm{NO}_{\mathrm{x}}$ and $\mathrm{NO}_{2}$ emissions from road traffic in Great Britain; Atmos. Environ. 54 $107-116$.
Beig G and Ali K 2006 Behavior of boundary layer ozone and its precursors over a great alluvial plain of the world: Indo-Gangetic plains; Geophys. Res. Lett. 33 L24813.

Bhuyan P K, Bharali C, Pathak B and Kalita G 2014 The role of precursor gases and meteorology on temporal evolution of $\mathrm{O}_{3}$ at a tropical location in northeast India; Environ. Sci. Pollut. Res., https://doi.org/10. 1007/s11356-014-2587-3.

Bishoi B, Prakash A and Jain V K 2009 A comparative study of air quality index based on factor analysis and US-EPA methods for an urban environment; Aerosol Air Qual. Res. 9 1-17.

Bond W D, Zhang R, Tie X, Brasseur G, Huffines G, Orville $\mathrm{R}$ E and Boccippio D J $2001 \mathrm{NO}_{\mathrm{x}}$ production by lightning over the continental United States; J. Geophys. Res. 106 27701-27710.

Castro T, Madronich S, Rivale S, Muhlia A and Mar B 2001 The influence of aerosols on photochemical smog in Mexico City; Atmos. Environ. 35 1765-1772.

Central Pollution Control Board (CPCB) The Gazette of India, National Ambient Air Quality Standards, New Delhi 2009.

Cetin E, Odabasi M and Seyfioglu R 2003 Ambient volatile organic compound (VOC) concentrations around a petrochemical complex and a petroleum refinery; Sci. Total Environ. 312(1) 103-112.

Clements N, Eav J, Xie M, Hannigan M P, Miller S L, Navidi W, Peel J L, Schauer J J, Shafer M M and Milford J B 2014 Concentrations and source insights for trace elements in fine and coarse particulate matter; Atmos. Environ. 89 $373-381$.

David L M and Nair P R 2011 Diurnal and seasonal variability of surface ozone and $\mathrm{NO}_{\mathrm{x}}$ at a tropical coastal site: Association with mesoscale and synoptic meteorological conditions; J. Geophys. Res. 116 D10303, https:// doi.org/10.1029/2010JD015076.

Debaje S B, Jeyakumar S J, Ganesan K, Jadhav D B and Seetaramayya P 2003 Surface ozone measurements at tropical rural coastal station Tranquebar, India; Atmos. Environ. 37 4911-4916.

Dickerson R R, Kondragunta S, Stenchikov G, Civerolo K L, Doddridge B G and Holben B N 1997 The impact of aerosols on solar ultraviolet radiation and photochemical Smog; Science 278(5339) 827-830.

Elminir H K 2005 Dependence of urban air pollutants on meteorology; Sci. Total Environ. 350 225-237, https:// doi.org/10.1016/j.scitotenv.2005.01.043.

Fuhrer J 2009 Ozone risk for crops and pastures in present and future climates; Naturwissenschaften 96173 194.

Fujita E M, Croes B E, Bennett C L, Lawson D R, Lurmann F W and Main H H 1992 Comparison of emission and ambient concentration ratios of $\mathrm{CO}, \mathrm{NO}_{\mathrm{x}}$, and $\mathrm{NMOG}$ in California's South Coast Air Basin; J. Air Waste Manag. Assoc. 42 264-276.

Gurjar B R, Jain A, Sharma A, Agarwal A, Gupta P, Nagpure A S and Lelieveld J 2010 Human health risks in megacities due to air pollution; Atmos. Environ. 44(36) 4606-4613.

Gopal K R, Lingaswamy A P, Arafath S M, Balakrishnaiah G, Kumari S P, Devi K U, Reddy N S K, Reddy K 
R O, Reddy R R, Azeem P A and Lal S 2014 Seasonal heterogeneity in ozone and its precursors $\left(\mathrm{NO}_{\mathrm{x}}\right)$ by insitu and model observations on semi-arid station in Anantapur (AP), south India; Atmos. Environ. 84294 306.

Im U, Poupkou A, Incecik S, Markakis K, Kindap T, Unal A, Melas D, Yenigun O, Topcu S, Odman MT, Tayanc M and Guler M 2011 The impact of anthropogenic and biogenic emissions on surface ozone concentrations in Istanbul; Sci. Total Environ. 409 1255-1265.

IPCC 2007 The Physical Science Basis; Contribution of Working Group I to the Fourth Assessment Report of the Intergovernmental Panel on Climate Change, Cambridge University Press, New York, USA.

Jacob D J 2000 Heterogeneous chemistry and tropospheric ozone; Atmos. Environ. 34 2131-2159.

Jacobson M Z 1998 Studying the effects of aerosols on vertical photolysis rate coefficient and temperature profiles over an urban airshed; J. Geophys. Res. 103 1059310604.

Jonson J E, Simpson D, Fagerli H and Solberg S 2006 Can we explain the trends in European ozone levels?; Atmos. Chem. Phys. 6 51-66.

Kulkarni P S, Bortoli D, Domingues A and Silva A M 2016 Surface ozone variability and trend over urban and suburban sites in Portugal; Aerosol Air Qual. Res. 16 138-152, https://doi.org/10.4209/aaqr.2015.02.0113.

Kumar R, Gupta A, Kumari K M and Srivastava S S 2004 Simultaneous measurements of $\mathrm{SO}_{2}, \mathrm{NO}_{2}, \mathrm{HNO}_{3}$ and $\mathrm{NH}_{3}$ : Seasonal and spatial variations; Curr. Sci. 87(8) 1108-1115.

Kumar U, Prakash A and Jain V K 2008 A photochemical modelling approach to investigate $\mathrm{O}_{3}$ sensitivity to $\mathrm{NO}_{\mathrm{x}}$ and VOCs in the urban atmosphere of Delhi; Aerosol Air Qual. Res. 8 147-159.

Lai T L, Talbot R and Mao H 2011 An investigation of two highest ozone episodes during the last decade in New England; Atmosphere 3(1) 59-86.

Lal S, Naja M and Subbaraya B H 2000 Seasonal variations in surface ozone and its precursors over an urban site in India; Atmos. Environ. 34 2713-2724.

Lal S, Sahu L K, Gupta S, Srivastava S, Modh K S, Venkataramani S and Rajesh T A 2008 Emission characteristic of ozone related trace gases at a semi-urban site in the Indo-Gangetic Plain using intercorrelations; J. Atmos. Chem. 60 189-204.

Lamarque J F, Brasseur G P, Hess P G and Muller J F 1996 Three dimensional study of the relative contribution of the different nitrogen sources in the troposphere; J. Geophys. Res. 101 22,955-22,968.

Lehman J, Swinton K, Bortnick S, Hamilton C, Baldridge E, Eder B and Cox B 2004 Spatio-temporal characterization of tropospheric ozone across the eastern United States; Atmos. Environ. 38 4357-4369, https://doi.org/10.1016/ j.atmosenv.2004.03.069.

Lelieveld J and Dentener F J 2000 What controls tropospheric ozone?; J. Geophys. Res. 105 35313551.

Li G, Bei N, Tie X and Molina L T 2011 Aerosol effects on the photochemistry in Mexico City during MCMA2006/MILAGRO campaign; Atmos. Chem. Phys. 11 5169-5182.
Mallik C, Lal S and Venkataramani S 2015 Trace gases at a semi-arid urban site in western India: Variability and inter-correlations; J. Atmos. Chem. 72(2) 143164.

Mauzerall D and Wang X 2001 Protecting agricultural crops from the effects of tropospheric ozone exposure: Reconciling science and standard setting in the United States, Europe, and Asia; Ann. Rev. Energ. Env. 26 237268.

Moorthy K K, Beegum S N, Babu S S, Smirnov A, John S R, Kumar K R, Narasimhulu K, Dutt C B S and Nair V S 2010 Optical and physical characteristics of Bay of Bengal aerosols during W-ICARB: Spatial and vertical heterogeneities in the marine atmospheric boundary layer and in the vertical column; J. Geophys. Res. 115 D24213, https://doi.org/10.1029/2010JD014094.

Naja M and Lal S 2002 Surface ozone and precursor gases at Gadanki $\left(13.5^{\circ} \mathrm{N}, 79.2^{\circ} \mathrm{E}\right)$, a tropical rural site in India; $J$. Geophys. Res. 107(D14) 4197, https://doi.org/10.1029/ 2001JD000357.

Naja M, Lal S and Chand D 2003 Diurnal and seasonal variabilities in surface ozone at a high altitude site $\mathrm{Mt} \mathrm{Abu}$ $\left(24.6^{\circ} \mathrm{N}, 72.7^{\circ} \mathrm{E}, 1689 \mathrm{~m}\right.$ asl $)$ in India; Atmos. Environ. 37 4205-4215.

Nair P R, Chand D, Lal S, Modh K S, Naja M, Parameswaran K and Venkataramani S 2002 Temporal variations in surface $\mathrm{O}_{3}$ at Thumba $\left(8.6^{\circ} \mathrm{N}, 77^{\circ} \mathrm{E}\right)-\mathrm{A}$ tropical coastal site in India; Atmos. Environ. 36 603610.

Nishanth T, Praseed K, Kumar M K S and Valsaraj K T 2012 Analysis of ground level $\mathrm{O}_{3}$ and $\mathrm{NO}_{x}$ Measured at Kannur, India; J. Earth Sci. Climate Change 3(1), https:// doi.org/10.4172/2157-7617.1000111.

Ojha N, Naja M, Singh K P, Sarangi T, Kumar R, Lal $\mathrm{S}$, Lawrence $\mathrm{M} \mathrm{G}$, Butler $\mathrm{T} \mathrm{M}$ and Chandola $\mathrm{H} \mathrm{C}$ 2012 Variabilities in ozone at a semi-urban site in the Indo-Gangetic Plain region: Association with the meteorology and regional processes; J. Geophys. Res.- Atmos. 117(D20).

Peng Y P, Chen K S, Lai C H, Lu P J and Kao J H 2006 Concentrations of $\mathrm{H}_{2} \mathrm{O}_{2}$ and $\mathrm{HNO}_{3}$ and Ozone sensitivity in the ambient air of southern Taiwan; Atmos. Environ. 40 6741-6751.

Peng Y P, Chen K S, Wang H K and Lai C H 2011 In situ measurements of hydrogen peroxide, nitric acid and reactive nitrogen to assess the ozone sensitivity in Pingtung County, Taiwan; Aerosol Air Qual. Res. 1159 69.

Pipal A S, Jan R, Satsangi P G, Tiwari S and Taneja A 2014 Study of surface morphology, elemental composition and origin of atmospheric aerosols (PM2.5 and PM10) over Agra, India; Aerosol Air Qual. Res. 14 1685-1700, https://doi.org/10.4209/aaqr.2014.01.0017.

Pitts F and Pitts B J 2000 Chemistry of the upper and lower atmosphere: Theory, experiments, and applications; Academic Press, San Diego, CA.

Putero D, Landi T C, Cristofanelli P, Marinoni A, Laj P, Duchi R, Calzolari F, Verza G P and Bonasoni P 2014 Influence of open vegetation fires on black carbon and ozone variability in the southern Himalayas (NCO-P, 5079 m a.s.l.); Environ. Pollut. $184597-$ 604 . 
Racherla P N and Adams P J 2008 The response of surface ozone to climate change over the eastern United States; Atmos. Chem. Phys. 8 871-885.

Reddy R R, Gopal K R, Reddy L S S, Narasimhulu K, Kumar K R, Ahammed Y N and Reddy C V K 2008 Measurements of surface ozone at semi-arid site Anantapur $\left(14.62^{\circ} \mathrm{N}, 77.65^{\circ} \mathrm{E}, 331 \mathrm{~m}\right.$ asl) in India; J. Atmos. Chem. 59 47-59.

Reddy K K, Naja M, Ojha N, Mahesh P and Lal S 2012 Influences of the boundary layer evolution on surface ozone variations at a tropical rural site in India; J. Earth Syst. Sci. 121(4) 911-922.

Renuka K, Gadhavi H, Jayarman A, Lal S, Naja M and Rao S V B 2014 Study of ozone and $\mathrm{NO}_{2}$ over Gadanki-a rural site in south India; J. Atmos. Chem. 71(2) 95-112.

Sandhya M, Sridharan S, Indira Devi M and Gadhavi H 2015 Tropical upper tropospheric ozone enhancements due to potential vorticity intrusions over Indian sector; J. Atmos. Sol.-Terr. Phys. 132 147-152.

Sarangi T, Naja M, Ojha N, Kumar R, Lal S, Venkataramani S, Kumar A, Sagar R and Chandola H C 2014 First simultaneous measurements of ozone, $\mathrm{CO}$, and $\mathrm{NO}_{\mathrm{y}}$ at a high-altitude regional representative site in the central Himalayas; J. Geophys. Res. Atmos. 119(3) 1592-1611.

Satsangi G S, Lakhani A, Kulshrestha P R and Taneja A 2004 Seasonal and diurnal variation of surface ozone and a preliminary analysis of exceedance of its critical levels at a semi-arid site in India; J. Atmos. Chem. 47 271-286.

Seinfeld J H and Pandis S N 2006 Atmospheric chemistry and physics; John Wiley and Sons, New Jersey, Hoboken.

Shan W, Yin Y, Lu H and Liang S 2009 A meteorological analysis of ozone episodes using HYSPLIT model and surface data; Atmos. Res. 93 767-776.

Sharma P, Kuniyal J C, Chand K, Guleria R P, Dhyani P $\mathrm{P}$ and Chauhan C 2013 Surface ozone concentration and its behaviour with aerosols in the northwestern Himalaya, India; Atmos. Environ. 71 44-53.

Sharma A, Mandal T K, Sharma S K, Shukla D K and Singh S 2016 Relationships of surface ozone with its precursors, particulate matter and meteorology over Delhi; J. Atmos. Chem. 74(4) 451-474, https://doi.org/10. 1007/s10874-016-9351-7.

Shukla K, Srivastava P K, Banerjee T and Aneja V P 2017 Trend and variability of atmospheric ozone over middle Indo-Gangetic Plain: Impacts of seasonality and precursor gases; Environ. Sci. Pollut. Res. 24 164-179, https://doi. org/10.1007/s11356-016-7738-2.

Sillman S 1995 The use of $\mathrm{NO}_{y}, \mathrm{H}_{2} \mathrm{O}_{2}$ and $\mathrm{HNO}_{3}$ as indicator for ozone- $\mathrm{NO}_{\mathrm{x}}$-hydrocarbon sensitivity in urban locations; J. Geophys. Res. 100(D7) 14175-14188.

Sillman S, He D, Cardelino C and Imhoff R E 1997 The use of photochemical indicators to evaluate Ozone- $\mathrm{NO}_{\mathrm{x}}-$ hydrocarbon sensitivity: Case studies from Atlanta, New York, and Los Angeles; J. Air Waste Manag. Assoc. 47 1030-1040.

Sillman S, He D, Pippin M R, Daum P H, Imre D G, Kleinman L I, Lee J H and Weinstein-Lloyd J 1998 Model correlations for ozone, reactive nitrogen and peroxides for Nashville in comparison with measurements: Implications for VOC-NOx sensitivity; J. Geophys. Res. 103 22,62922,644 .
Sillman S 1999 The relation between ozone, $\mathrm{NO}_{\mathrm{x}}$, and hydrocarbons in urban and polluted rural environments; Atmos. Environ. 33 1821-1845.

Sillman S and He D 2002 Some theoretical results concerning $\mathrm{O}_{3}, \mathrm{NO}_{\mathrm{x}}-\mathrm{VOC}$ chemistry and $\mathrm{NO}_{\mathrm{x}}-\mathrm{VOC}$ indicators; J. Geophys. Res. 107(D22), https://doi.org/10.1029/ 2001JD001123.

Singla V, Satsangi A, Pachauri T, Lakhani A and Kumari K M $2011 \mathrm{O}_{3}$ formation and destruction at a sub-urban site in north central region of India; Atmos. Res. 101 373-385.

Singla V, Pachauri T, Satsangi A, Kumari K M and Lakhani A 2012 Surface ozone concentrations in Agra: Links with the prevailing meteorological parameters; Theor. Appl. Climatol. 110(3) 409-421.

Sitch S, Cox P M, Collins W J and Huntingford C 2007 Indirect radiative forcing of climate change through ozone effects on the land-carbon sink; Nature 448(7155) 791794 .

Solomon P, Cowling E, Hidy G and Furiness C 2000 Comparison of scientific findings from major ozone field studies in North America and Europe; Atmos. Environ. 34(12) 1885-1920.

Swamy Y V, Venkanna R, Nikhil G N, Chitanya D N S K, Sinha P R, Ramakrishna M and Rao A G 2012 Impact of nitrogen oxides, volatile organic compounds and black carbon on atmospheric ozone levels at a semi-arid urban site in Hyderabad; Aerosol Air Qual. Res. 12 662671.

Tseng K H, Wang J L, Chen M T and Tsuang B J 2009 Assessing the relationship between air mass age and summer ozone episodes based on photochemical indices; Aerosol Air Qual. Res. 9 149-171.

Tu J, Xia Z, Wang H and Li W 2007 Temporal variations in surface ozone and its precursors and meteorological effects at an urban site in China; Atmos. Res. 85310 337.

Verma N, Satsangi A, Lakhani A and Kumari K M 2015 Prediction of ground level Ozone concentration in ambient air using multiple regression analysis; J. Chem. Biol. Phys. Sci. 5(4) 3685-3696.

Verma N, Satsangi A, Lakhani A and Kumari K M 2016 Low molecular weight monocarboxylic acids in $\mathrm{PM}_{2.5}$ and $\mathrm{PM}_{10}$ : Quantification, seasonal variation and source apportionment; Aerosol Air Qual. Res., https://doi.org/ 10.4209/aaqr.2016.05.0183.

Wang Y, Zhang X and Draxler R R 2009 TrajStat: GIS-based software that uses various trajectory statistical analysis methods to identify potential sources from long-term air pollution measurement data; Environ. Model Softw. 24 938-939.

Xu J, Zhang Y, Zheng S and He Y 2012 Aerosol effects on ozone concentrations in Beijing: A model sensitivity study; J. Environ. Sci. 24(4) 645-656.

Yadav S, Praveen O D and Satsangi P G 2015 The effect of climate and meteorological changes on particulate matter in Pune, India; Environ. Monit. Assess. 187(7) 402.

Yadav R, Sahu L K, Beig G and Jaaffrey S N A 2016 Role of long-range transport and local meteorology in seasonal variation of surface ozone and its precursors at an urban site in India; Atmos. Res. 176 96-107. 
Yang K H, Ting C C, Wang J L, Wingenter O W and Chan C C 2005 Diurnal and seasonal cycles of ozone precursors observed from continuous measurement at an urban site in Taiwan; Atmos. Environ. 39 2829-2838.
Zhang R, Sarwar G, Fung J C H and Lau A K H 2013 Role of photoexcited nitrogen dioxide chemistry on ozone formation and emission control strategy over the Pearl River Delta, China; Atmos. Res. 132-133 332-344.

Corresponding editor: A K PATRA 